\title{
Staggered Boards and the Wealth of Shareholders: Evidence from Two Natural Experiments
}

\section{Citation}

Lucian A. Bebchuk, Alma Cohen, and Charles C.Y. Wang, Staggered Boards and the Wealth of Shareholders: Evidence from Two Natural Experiments (Harvard John M. Olin Discussion Paper Series, No. 697, June 2011).

\section{Published Version}

http://www.law.harvard.edu/programs/olin_center/papers/pdf/Bebchuk_et\%20al_697.pdf

\section{Permanent link}

http://nrs.harvard.edu/urn-3:HUL.InstRepos:30064394

\section{Terms of Use}

This article was downloaded from Harvard University's DASH repository, and is made available under the terms and conditions applicable to Other Posted Material, as set forth at http:// nrs.harvard.edu/urn-3:HUL.InstRepos:dash.current.terms-of-use\#LAA

\section{Share Your Story}

The Harvard community has made this article openly available.

Please share how this access benefits you. Submit a story.

Accessibility 
ISSN 1936-5349 (print)

ISSN 1936-5357 (online)

\title{
HARVARD
}

JOHN M. OLIN CENTER FOR LAW, ECONOMICS, AND BUSINESS

\section{STAGGERED BOARDS AND THE WEALTH OF SHAREHOLDERS: EVIDENCE FROM TWO NATURAL EXPERIMENTS}

\author{
Lucian A. Bebchuk, Alma Cohen, and Charles C. Y. Wang
}

Discussion Paper No. 697

$6 / 2011$

Harvard Law School

Cambridge, MA 02138

This paper can be downloaded without charge from:

The Harvard John M. Olin Discussion Paper Series:

http://www.law.harvard.edu/programs/olin_center/

The Social Science Research Network Electronic Paper Collection: http://ssrn.com/abstract=1706806

This paper is also a discussion paper of the

John M. Olin Center's Program on Corporate Governance 


\title{
Staggered Boards and the Wealth of Shareholders: Evidence from Two Natural Experiments
}

\author{
Lucian A. Bebchuk, ${ }^{*}$ Alma Cohen, ${ }^{* *}$ and Charles C.Y. Wang ${ }^{* * *}$
}

\begin{abstract}
While staggered boards have been documented to be negatively correlated with firm valuation, such association might be due to staggered boards either bringing about lower firm value or merely reflecting the tendency of low-value firms to have staggered boards. In this paper, we use two natural experiments to shed light on the causality question. In particular, we focus on two recent court rulings, separated by several weeks, that affected in opposite directions the antitakeover force of staggered boards: (i) a ruling by the Delaware Chancery Court approving the legality of shareholder-adopted bylaws that weaken the antitakeover force of a staggered board by moving the company's annual meeting up from later parts of the calendar year to January, and (ii) the subsequent decision by the Delaware Supreme Court to overturn the Chancery Court ruling and invalidate such bylaws.

We find evidence consistent with the hypothesis that the Chancery Court ruling increased the value of affected companies - namely, companies with a staggered board and an annual meeting in later parts of the calendar year - and that the Supreme Court ruling produced a reduction in the affected companies' value. The identified effects were most pronounced for firms for which control contests are especially relevant due to relative underperformance, small firm size, high asset pledgibility, or high takeover intensity in their industry.

Our findings have implications for the long-standing debate on staggered boards. The findings are consistent with the market's viewing staggered boards as bringing about a reduction in firm value. Our findings are thus consistent with leading institutional investors' policies in favor of board de-staggering, and with the view that the ongoing process of board de-staggering in public firms can be expected to enhance shareholder value.
\end{abstract}

Keywords: Corporate governance, staggered boards, takeover defenses, antitakeover provisions, proxy fights, Tobin's Q, firm value, agency costs, Delaware, chancery court, Airgas.

JEL Classifications: G30, G34, K22

\footnotetext{
${ }^{*}$ Harvard Law School and NBER.

** Tel-Aviv University Eitan Berglas School of Economics, NBER, and Harvard Law School.

*** Stanford University Department of Economics and Harvard Law School.

For helpful comments on earlier drafts, we are grateful to Steven Davidoff, Jeff Gordon, Guhan Subramanian, and participants in a Harvard workshop. We have also benefitted from conversations with a number of participants in the Airgas takeover battle and the market trading surrounding it, including Isaac Corree, Jeff Gordon, Matthew Mark, David Millstone, Ted Mirvis, and Tim Wallach.
} 


\section{Introduction}

The existence of governance provisions that weaken shareholder rights and insulate directors from removal is now well known to be negatively correlated with firm value (Gompers, Ishii, and Metrick (2003)). This correlation is partly driven by the negative correlation between firm value and staggered board provisions, which prevent shareholders from removing a majority of directors in any given shareholder meeting (Bebchuk and Cohen (2005); Bebchuk, Cohen, and Ferrell (2009)). It might be suggested, however, that such correlation does not imply causation, and that it might be fully driven by the tendency of firms with low value and weak performance to have entrenching provisions in general and staggered boards in particular. In this paper we seek to contribute to understanding the causality question by studying two natural experiments two court rulings that affected the extent to which staggered boards can impede shareholders seeking to replace a majority of directors. We find evidence consistent with market participants' viewing the antitakeover force of staggered boards as value-reducing.

Our results have significant policy implications for the long-standing debate on staggered boards and for the struggle between institutional investors and companies over the subject. Over time, institutional investors have become increasingly opposed to staggered boards. While shareholders were willing to vote for adopting a staggered board during the 1980s, they have generally been unwilling to do so since the early 1990s and have been increasingly willing to support shareholder proposals to dismantle staggered boards. According to Georgeson Shareholder reports, the average percentage of votes cast in favor of proposals to de-stagger boards exceeded 65\% in each of the five proxy seasons from 2006 through 2010. The Council of Institutional Investors, ${ }^{1}$ major institutional investors such as the American Funds, BlackRock, CalPERS, Fidelity, TIAA-CREF, and Vanguard, ${ }^{2}$ and the two leading proxy advisors ISS and

(C) 2011 Lucian A. Bebchuk, Alma Cohen, and Charles C.Y. Wang. All rights reserved.

${ }^{1}$ See Council of Institutional Investors, Corporate Governance Policies, at p. 3.

2 See American Funds, Proxy Voting Procedures and Principles, p. 3; BlackRock, Proxy Voting Guidelines for U.S. Securities, at p. 6; California Public Employees Retirement System, Global Principles of Accountable Corporate Governance, p. 17; Fidelity Investments, Corporate Governance and Proxy Guidelines, p. 11; TIAA-CREF, Policy Statement on Corporate Governance, p. 31; Vanguard, Vanguard's proxy voting guidelines, p. 2. 
Glass Lewis, ${ }^{3}$ all have policies favoring annual election of all directors and board de-staggering proposals.

Facing such widespread shareholder opposition to staggered boards, many companies, especially large companies receiving the most attention from investors seeking governance improvements, have chosen during the past decade to eliminate staggered boards; according to FactSet Research Systems, the number of S\&P 500 companies with staggered boards declined by more than $40 \%$ from 2000 to 2009. Many companies with staggered boards, however, continue to resist investor pressure to de-stagger, express strong opposition to proposals to de-stagger their board, and argue that staggered boards enhance rather than reduce shareholder value. ${ }^{4}$ At present, about half of the publicly traded companies in the over 3,000 public companies whose takeover defenses are tracked by FactSet Research Systems still have a staggered board. The stakes in the debate on staggered boards are thus large.

We seek to contribute to understanding the effects of a staggered board. Causal identification is notoriously difficult in empirical work on corporate finance and corporate governance. We use a quasi-experimental research design, focusing on the effects of two notfully-anticipated court rulings. In particular, we focus on the Chancery Court and Supreme Court rulings on October 8, 2010 and November $23^{\text {rd }}, 2010$, respectively, in the takeover battle between Airgas Inc. ("Airgas") and Air Products and Chemicals, Inc. ("Air Products").

The rulings focused on the permissibility of adopting a shareholder-adopted bylaw -conceived in the course of the Airgas takeover battle - that moves up the date of the next calendar year's annual meeting to January. Such a bylaw has the potential of shortening the tenure of directors and facilitating the process of replacing a majority of the company's directors. For companies whose annual meetings ordinarily took place in later parts of the calendar year (as was the case with Airgas whose annual meetings have typically been held in August or September), permitting such bylaws would reduce the extent to which staggered boards can delay the replacement of a majority of directors and thus lower the impediments to a hostile takeover. Chancellor Chandler of the Delaware Chancery Court initially ruled that such bylaws

\footnotetext{
${ }^{3}$ RiskMetrics Group, 2010 U.S. Proxy Voting Guidelines Summary, p. 18.

${ }^{4}$ For examples of statements of boards of directors in opposition to shareholder proposals in favor of board de-staggering brought to a vote in 2010 annual meetings, see the 2010 proxy statements of Abercrombie \& Fitch Co., Bancorp South, Inc., and Hospitality Properties Trust.
} 
may be used. Subsequently, however, the Delaware Supreme Court reversed and held such shareholder-adopted bylaws to be invalid.

We examine the cross-section of stock returns surrounding the announcements of the rulings, focusing on the value of the companies affected by the above two rulings - companies with a staggered boards whose annual meeting has been taking place in later parts of the calendar year. We find evidence consistent with the hypothesis that the value of these companies was increased by the first ruling, which validated the novel method for weakening the antitakeover force of companies' staggered boards. We also find evidence consistent with the hypothesis that the second ruling, which invalidated this novel method, had a negative effect on the value of these companies that was of a similar magnitude to that of the first ruling's (positive) effect. The initial increase in value, and the subsequent reduction, was especially pronounced for companies for which control contests are especially relevant due to relative underperformance, high asset pledgibility, small firm size, or high deal intensity in the industry.

Overall, our findings are consistent with market participants' expecting the weakening of the antitakeover effect of staggered boards to bring about an increase in firm value. These findings are thus consistent with the large support among institutional investors for proposals to repeal staggered boards. The findings are also consistent with the view that the continued destaggering of boards - an ongoing process that has been taking place over the past decade - can be expected to benefit shareholders. The identified abnormal positive returns accompanying the Chancery Court ruling, and the abnormal negative returns accompanying the Supreme Court ruling, are likely to understate the market's estimate of the benefits of repealing staggered boards because (i) as will be discussed, the market ascribed a positive probability to each of the ruling before they were issued, and (ii) the bylaws that were the subject of the rulings would have weakened but not eliminated the antitakeover force of staggered boards in the companies affected by the rulings.

Our work seeks to contribute to the existing body of empirical work on staggered boards. Focusing on a sample of hand-collected targets of hostile takeovers, Bebchuk, Coates, and Subramanian (2002a, 2002b) found that, among takeover targets, those with a staggered board are associated with lower gains to shareholders following the receipt of a tender offer. Examining the 1,500+ public firms in the IRRC dataset, Bebchuk and Cohen (2005) 
subsequently documented that staggered boards are associated with lower firm valuation as proxied by Tobin's Q. Subsequently, Masulis, Wang, and Xie (2007) found that firms with staggered boards are associated with value-decreasing acquisition decisions; and Faleye (2007) reported that staggered boards are associated with lower sensitivity of compensation to performance and lower sensitivity of CEO turnover to firm performance. Bates, Becher and Lemmon (2008) reported that staggered boards have a positive correlation with higher takeover premiums, but this study also reports that staggered boards are associated with a lower likelihood of an acquisition, and confirms, consistent with earlier work, that staggered boards are overall associated with lower firm valuation. We seek to contribute to this body of work by using a quasi-experimental setting to study whether the identified correlation between staggered boards and lower firm value is at least partly driven by staggered boards bringing about a lower firm value. $^{5}$

Our study also builds on the event study literature using stock price reactions to study the wealth effects of regulatory changes, beginning with Schwert (1981) (see MacKinlay (1997) for a review of the application of event studies to economics and finance, and Bhagat and Romano (2002) for a survey of such applications in corporate law). We add to the work using e event studies to study the effects of governance arrangements. ${ }^{6}$ The challenges facing event studies of

5 Bebchuk and Cohen (2005) explore the causality issue by using staggered boards in 1990 as an instrument, obtaining evidence consistent with the correlation between staggered boards and lower firm value being at least partly driven by staggered boards' operating to reduce firm value. This evidence, however, is offered as being merely suggestive on the causality issue.

We also wish to note the results of Guo, Kruse, and Nohel (2008), who find positive stock market reactions to announcements by companies on plans to de-stagger. While the results of Guo et al. are consistent with ours, it is difficult to draw causal inferences from their findings because management decisions to de-stagger are unlikely to be random, but rather may tend to be taken by managements that anticipate improvements in firm value that would make them less vulnerable to a control contest in any event, and may thus be a signal to the market about management's positive inside assessment. An earlier paper by Bhagat and Jeffries (1991), using data from the 1980s during which antitakeover amendments often passed, studied the returns accompanying the announcement of such amendments (in general, not only resulting in a staggered board).

${ }^{6}$ For example, Chhaochharia and Grinstein (2007) and Hochberg, Sapienza, and Vissing-Jorgensen (2009) use stock returns to study the effects of the Sarbanes-Oxley Act; and Larcker, Ornazabal, and Taylor (2010) and Becker, Bergstresser, and Subramanian (2010) analyze stock returns to study the expected effects of proxy access reform. 
governance changes are now well-understood: event studies focusing on governance changes adopted by companies bundle together the market's assessment of the changes with the market's inferences concerning the private information that might have led management to make such changes (see, e.g., Binder (1985), Coates (2000)); and events focusing on legislative adoption of new arrangements (e.g., Karpoff and Malatesta (1989)) might face the difficulty that market participants might at the time of adoption not have accumulated yet have experience with the consequences of the newly adopted arrangements; . The pair of rulings on which the current study focuses provides a good quasi-experimental setting: it involves exogenous changes that took place at clear points in time and were not fully anticipated prior to that point in time; the changes were to an arrangement - staggered boards - with whose consequences market participants have had a great deal of experience over the preceding two decades; and we are assisted by the fact that we have two events, each affecting the same set of companies but in the opposite direction than the other.

The remainder of this paper is organized as follows. Section 2 discusses the relevant institutional background, including the Delaware Chancery and Supreme Court rulings which are the focus of our study. Section 3 describes our data and provides summary statistics. Section 4 shows that the stock returns accompanying the two rulings are consistent with the market's viewing staggered boards as bringing about a lower firm value. Section 5 concludes.

\section{Staggered Board and the Airgas Ruling}

\subsection{Staggered Boards}

A company may have a unitary or a staggered board. In a unitary board structure, all directors stand for election at each annual meeting. By contrast, in a staggered board structure, directors are grouped into separate classes, typically three classes, with only one of the classes coming up for re-election at each shareholder annual meeting. A staggered board structure therefore provides incumbent directors with substantial protection from attempts to gain control via either a proxy fight or a takeover bid.

In a proxy fight over a company with a staggered board, a challenger would not be able to gain control of the board in one annual meeting but would need to win a shareholder vote in two 
consecutive shareholder meetings. Thus, even a competing team that is viewed as superior by shareholders would face a substantial delay in its attempt to gain control. Furthermore, the prospect of a board that is bitterly split in the period between the two shareholder meetings might discourage some shareholders from voting for a challenger they would support if a clean-cut transition were possible.

Staggered boards also provide substantial protection against hostile bidders because, following the development of the poison pill, a hostile bidder can prevail over incumbent opposition only by getting shareholders to replace the majority of the incumbent directors. U.S. law has developed during the 1980s and early 1990s to allow incumbents to adopt and maintain poison pill plans that, as long as they are in place, make it prohibitively expensive for a bidder to purchase a large block. As a result, the only route left for hostile bidders is to put an attractive offer on the table and persuade shareholders to replace the incumbents with a slate of directors receptive to the acquisition bid, typically nominated by the bidder itself. Once elected, such a slate of directors would redeem the poison pill and make the acquisition possible.

Thus, a hostile takeover requires a ballot box replacement of a majority of directors and is hence made more difficult by the presence of a staggered board. With a staggered board, no matter how attractive a bidder's offer is, the bidder would have to win in two consecutive annual meetings. In fact, the evidence indicates that takeover targets are substantially more likely to be able to fend off a hostile takeover bid and remain independent when their board is staggered (Bebchuk, Coates, and Subramanian 2002).

\subsection{The Airgas Bylaw}

The takeover battle that has led to the ruling on which we focus has been waged for over a year, and a good account of it can be obtained from a series of Deal Professor columns written for the New York Times online by Professor Steven Davidoff. ${ }^{7}$ The saga began in October 2009,

7 See Davidoff, "The Way Forward for Airgas," New York Times online, March 19, 2010; Davidoff, "The Air Products-Airgas Battle Heats Up," New York Times online, May 14, 2010; Davidoff, "Airgas Rolls the Dice in Proxy Fight," New York Times online, August 30, 2010; Davidoff, "Airgas's Novel Question," New York Times online, September 1, 2010; Davidoff, “After Losing Vote, What's Next for Airgas?," New York Times online, September 16, 2010; Davidoff, "Air Products Wins Round in Battle With Airgas," New York Times online, October 8, 2010; Davidoff, "The Dwindling Options for Airgas," 
when Air Products expressed an interest in acquiring Airgas. Air Products made three offers over the following four months, which were all rejected by Airgas' board of directors. In February of 2010, Airgas rejected Air Products' \$5 billion, all-cash tender offer to acquire 100\% of Airgas' shares. ${ }^{8}$

Facing the opposition of the Airgas board, Air Products proceeded to a proxy fight at the shareholder meeting of Airgas in September 2010. Because Airgas has a staggered board, only one-third of its nine directors came up for re-election at the meeting. With a majority of Airgas' shareholders seemingly supportive of its acquisition attempt, Air Products was able to replace the directors coming up for re-election with three individuals nominated by Air Products.

In past calendar years, Airgas held its annual meetings no earlier than August, and thus, in the ordinary course of events, Air Products would have been expected to have to wait a year to get an opportunity to replace another one-third of Airgas' directors and pave the way for an acquisition. In this case, however, Air Products made a novel move, which seems to have been first suggested in one of the Professor Davidoff's Deal Professor columns. ${ }^{9}$ At the September 2010 annual meeting, Air Products obtained majority shareholder approval for a new shareholder-adopted bylaw provision ("the Airgas Bylaw"), which specified that the next annual meeting will be held on January 18, 2011, a mere four months after the September 2010 annual meeting.

Airgas turned to the Delaware Chancery Court, seeking to invalidate the bylaw. Airgas argued that the staggered board structure established in Airgas' charter is inconsistent with the shortening of the directors' terms that the bylaw would have produced, and that the bylaw is thus impermissible as contrary to the charter. Airgas warned that interpreting the standard language used in its charter as permitting shareholders to adopt bylaws such as the Airgas bylaw would dilute the significance of having a staggered board in many companies. In response, Air Products argued that the charter provision establishing a staggered board should be interpreted as

New York Times online, October 11, 2010. Davidoff, “Airgas's Strategic Blink," NY Times online, October 28, 2010.

${ }^{8}$ On February 11, Air Products announced an all-cash tender offer at that price for $100 \%$ of the Airgas shares for \$60/share, which was again rejected by Airgas. Air Products continued to raise its bid over the next few months, all met with a cool rejection: on July 8 , it increased its offer to $\$ 63.50 /$ share; and on September 6, 2010, it again raised its bid to $\$ 65.50 /$ share.

${ }^{9}$ See Steven M. Davidoff, “The Way Forward for Airgas,” New York Times online, March 19, 2010. 
requiring only that one-third of the directors come up for election in each calendar year's annual meeting, without limiting the ability of bylaws to specify the time during the calendar year in which the annual meeting will take place.

The litigation attracted significant attention because of its implications for other publicly traded companies - namely, other companies with a staggered boards and an annual meeting ordinarily taking place in later parts of the calendar year. ${ }^{10}$ To the extent that bylaws such as the Airgas bylaw are permitted, the antitakeover force of these companies' staggered boards would be weakened, as shareholders favoring a premium offer blocked by incumbent directors would be able to pass such a bylaw and shorten the delay required for replacing a majority of the board. Following the Chancery Court ruling permitting such bylaws, the Deal Professor column stated that the opinion "blows a hole in the defenses of many companies with staggered boards" and that these companies "will have to live with the fact that a staggered board can be weakened by forcing a subsequent annual meeting to occur much sooner than people thought." Conversely, to the extent that such bylaws are impermissible, as the Delaware Supreme Court ultimately held, the antitakeover force of these companies' staggered boards will remain intact and the "hole in the defenses" will be filled. ${ }^{11}$

\subsection{The October $8^{\text {th }}$ Chancery Court Ruling}

As is common in the courts of Delaware, the litigation over the permissibility of the Airgas bylaw proceeded quickly, with a final hearing taking place in the Delaware Court of Chancery on Friday October $8^{\text {th }}, 2010$. That evening, after the close of the stock market, Chancellor Chandler issued an opinion that sided with Air Products and approved the legality of the Airgas bylaw. ${ }^{12}$ Chandler concluded that the question of whether the Airgas bylaw is

\footnotetext{
${ }^{10}$ At the time of the Airgas rulings, companies' ordinary timing of the annual meeting within the calendar year did not seem to reflect companies' setting of the level of antitakeover protection. As noted earlier, the use of an Airgas-type bylaw in the context of a takeover battle was a novel technique first conceived for and tried in the Airgas 2010 takeover saga. Prior to this battle, the choice of the annual meeting timing was generally not viewed as relevant for corporate control purposes, and was made on the basis of various historical and logistical considerations.

${ }^{11}$ See Steven M. Davidoff, "Air Products Wins Round in Battle with Airgas," New York Times online, October 8, 2010.

${ }^{12}$ Airgas, Inc. v. Air Products and Chemicals, Inc., Chancery Court opinion, Decided October 8, 2010.
} 
permissible is not unambiguously answered by studying the language of the charter provision establishing the staggered board, and that this ambiguity should be resolved by reference to a presumption in favor of the shareholder franchise.

Chancellor Chandler's ruling was not a complete surprise to the market. For instance, the widely followed Deal Professor column as well as the M\&A Law Prof blog argued prior to the ruling that such an outcome was warranted on the merits and thus could well be expected. ${ }^{13}$ While Chancellor Chandler's ruling was not a complete surprise, however, it was not fully anticipated by the market either. In fact, at the time of the hearing in the Chancery Court on Friday, October 8, there was a downward movement in the stock price of Airgas, which a Deal Professor column covering the hearing attributed to market participants updating upwards the likelihood of an Airgas victory in light of certain remarks made by the Chancellor. ${ }^{14}$ Furthermore, that the ruling was not fully anticipated by the market is suggested by the immediate post-ruling change in Airgas' stock price. Airgas stock price rose by $2.7 \%$ at the very beginning of the first trading day (October 11, 2010) after the ruling was announced on the preceding Friday evening. ${ }^{15}$

The not-fully-anticipated nature of Chancellor Chandler's ruling gives rise to a natural experimental setting. The ruling was expected, to the extent that it would not be overturned on appeal, to weaken the insulating power of staggered boards of those companies whose annual meetings ordinarily takes place in later parts of the calendar year. Thus, a finding that the ruling was accompanied by positive abnormal returns to such companies (relative to non-impacted companies) would be consistent with the market's viewing the antitakeover force of staggered boards as value-decreasing.

\footnotetext{
${ }^{13}$ See Davidoff, “Airgas's Novel Question,” New York Times, September 1, 2010. Davidoff, “After Losing Vote, What's Next for Airgas?," New York Times online, September 16, 2010; Brian JM Quinn, “Advantage: Air Products,” M\&A Law Prof Blog, October 8, 2010.

${ }^{14}$ See Davidoff, "The Dwindling Options for Airgas," New York Times online, October 11, 2010.

${ }^{15}$ The view that the Chancery Court ruling was uncertain prior to its announcement - that is, that the ruling announced was neither a complete surprise nor fully anticipated - was also confirmed in conversations we had with market participants involved in the Airgas litigation and in M\&A arbitrage trading in Airgas stock during the relevant period.
} 


\subsection{The November $23^{\text {rd }}$ Supreme Court Ruling}

After the initial Chancery Court decision, Airgas appealed to the Supreme Court of Delaware, which held a hearing over the case on November $2^{\text {nd }}$. Although the Delaware Supreme Court was expected to announce its decision within days of the hearings, as was commonly the case in Delaware Supreme Court rulings in fast-paced takeover battles, the Supreme Court announced its decision only three weeks later, on November $23,2010 .{ }^{16}$

Instead of focusing on the language of the standard charter provision establishing a staggered board, as did the Chancery Court, the Supreme Court's interpretation of the charter provision relied substantially on "extrinsic evidence," such as the description of the chapter provision by commentators and in company disclosures. The Supreme Court concluded that the standard language of the staggered board provisions should be understood to require that directors serve for three years and thus to preclude Airgas-type bylaws that shorten this term significantly by moving up the annual meeting to the beginning of the calendar year. The Supreme Court ruling thus closed the door - opened up by the Chancery Court ruling - for using Airgas-type bylaws to weaken the force of the staggered boards of companies whose annual meeting ordinarily takes place in later parts of the year.

As was the case with the Chancery Court ruling, the Supreme Court ruling was not completely unexpected. During the November 8, 2010 hearing at the Delaware Supreme Court, the Supreme Court Justices directed tough questions to Air Products' counsel which led some market participants to raise their estimate of the likelihood of the Supreme Court's reversing the lower court ruling. ${ }^{17}$ Furthermore, the Supreme Court's delay in announcing a decision was viewed by market participants as increasing the likelihood of the Supreme Court's finding the Airgas bylaw to be invalid; had the Court planned to validate the bylaw and thus pave the way for a shareholder meeting in two months, the Court would have had strong reason to try to announce its decision quickly to facilitate preparing for the resulting January 2011 meeting.

\footnotetext{
${ }^{16}$ Airgas, Inc. v. Air Products and Chemicals, Inc., Delaware Supreme Court opinion, Decided November 23, 2010, C.A. No. 5817.

${ }^{17}$ See, e.g., Davidoff, "Staggered Boards and Company Value", New York Times online, November 12, 2010 (stating that "the questioning of the justices makes me ever so slightly more inclined to see the possibility of a reversal").
} 
As was the case with the Chancery Court ruling, however, the Supreme Court ruling was not fully anticipated by the market. Although Professor Davidoff revised the likelihood of reversal afterwards in light of the justices' questioning at the Supreme Court hearing, his Deal Professor column continued to predict that the Supreme Court would likely affirm the lower court's ruling. ${ }^{18}$ Furthermore, the stock price of Airgas fell significantly upon the announcement of the Supreme Court's opinion at 1:30PM on November $23^{\text {rd }}{ }^{19}$ which is consistent with the market not being certain that Airgas would win prior to the issuance of the decision. ${ }^{20}$

The not-fully-anticipated nature of the Supreme Court ruling provides us with another good natural experiment setting for studying market participants' view on how staggered boards affect firm value. By overturning the lower court ruling that weakened the insulating power of staggered boards of companies whose annual meetings ordinarily takes place in later parts of the calendar year, the Supreme Court ruling returned this insulating power of the companies' staggered boards to pre-Airgas levels. Thus, a finding that the ruling was accompanied by negative abnormal returns to such companies (compared to non-impacted ones) would be consistent with the market's viewing the power of staggered boards to delay director replacement by shareholders as value-decreasing.

\section{Data and Summary Statistics}

We gather data on corporate governance characteristics, in particular the presence of a staggered board, from the Shark Repellent dataset of FactSet Research Systems. The data is

\footnotetext{
${ }^{18}$ See Davidoff, “Airgas's Strategic Blink”, New York Times online, October 28, 2010.

${ }^{19}$ It should be noted, however, that the decline in Airgas' stock price was due both to the Supreme Court ruling that the Airgas bylaw is invalid and to the comments in the Supreme Court's opinion, that signaled acceptance of the blocking of Air Product's' bid by Airgas' directors. These comments could have reduced the market's estimate of the likelihood that the litigation ongoing at the time over whether Airgas' directors should be required to put out the poison pill would result in such an outcome.

${ }^{20}$ As was the case with the Chancery Court ruling, the view that the Supreme Court ruling was uncertain prior to its announcement - that is, that the ruling announced was neither a complete surprise nor fully anticipated - was also confirmed in conversations we had with market participants involved in the Airgas litigation and in M\&A arbitrage trading in Airgas stock during the relevant period.
} 
available on a cross-section of U.S. based firms listed on NYSE, NYSE AMEX, NYSE ARCA, NASDAQ, or NASDAQ Capital Market. ${ }^{21}$

We merge in data on stock prices and returns. In particular, we obtain October and November 2010 stock prices and returns from Datastream, and PERMNO identifiers and historical returns from CRSP.

Finally, we obtain GVKEY identifiers, GICS industry classification, and most recently available annual financial statement information from Compustat. Throughout the paper we use 6-digit GICS industry classification, which has been shown to better explain stock return comovements and cross-sectional variation in key financial ratios such as valuation multiples (see, e.g., Bhojraj, Lee, and Oler (2003)), and therefore provides a better classification system to form industry comparison groups. However, using the Fama-French 48 industry definitions does not significantly change our results.

The intersection of the above four datasets provides a sample of 3,216 firms. For our empirical analysis, we follow the governance literature (see GIM (2003)) and exclude all dualclass firms and real estate investment trusts (REITS) since they operate under unique corporate governance arrangements. ${ }^{22}$ We also exclude all firms in which insider equity ownership exceeds $50 \%$ for which the possibility of a control contest is irrelevant regardless of whether the board is staggered; keeping these observations in the dataset does not qualitatively change our results. Our final sample consists of 2,633 firms.

Table I reports summary statistics for our primary variables of interest on our sample of firms, and for the subset of firms with and without a staggered board. As the Table indicates, our sample is roughly evenly split between firms with a staggered board (47\%) and firms without a staggered board (53\%). Firms with and without a staggered board are similar in terms of the month in which the last annual meeting took place; the median meeting month for firms with and without a staggered board is the fifth month of May, and the standard deviation of the meeting month variable is 2.0 and 2.2 for firms with and without a staggered board, respectively.

\footnotetext{
${ }^{21}$ Shark Repellent data current as of October 12, 2010.

${ }^{22}$ REITs are defined as any firms with 4-digit SIC code of 6798.
} 
Table I also provides summary statistics concerning the distribution of characteristics that could make control contests more relevant for a firm: Return on Assets (ROA) ${ }^{23}$ and Tobin's $\mathrm{Q}^{24}$ which reflect a company's performance; PP\&E to Total Assets Ratio ${ }^{25}$ and Cash to Total Assets Ratio, ${ }^{26}$ which reflect the extent to which the firm's assets can be easily pledged and thus the ease with which a takeover could be financed; market capitalization, ${ }^{27}$ as small firms are known to be more likely to be acquired (see, e.g., Bats, Becher, and Lemmon (2008) and Bebchuk, Cohen, and Wang (2010)); and industry takeover intensity. ${ }^{28}$ With the exception of market capitalization and takeover intensity, each of the above variables are industry-median adjusted; that is, we subtract for each firm-year observation the respective variable's 6-digit GICS industry median value from the same fiscal year. Compared with companies with a staggered board, companies without a staggered board have a somewhat higher median industryadjusted Tobin's Q, median industry-adjusted return on assets, median takeover intensity, and median market capitalization, somewhat lower industry-adjusted cash to assets ratio, and similar median industry-adjusted PP\&E to assets ratios. In both types of companies, however, there is a substantial variation in each of these six variables.

\section{Announcement Returns around the Two Court Rulings}

\subsection{The Treatment Group}

In our natural experiment setup, the firms that are meaningfully affected by the Chancery Court ruling (as well as its subsequent reversal by the Delaware Supreme Court) - that is, our "treatment group" - are firms that, like Airgas itself, have a staggered board and have their

\footnotetext{
${ }^{23}$ Return on assets is defined as operating income divided by book value of assets from end of previous fiscal year.

${ }^{24}$ Following prior work, we use the definition of Tobin's Q in Kaplan and Zingales (1997), who define Tobin's Q as the market value of assets plus the market value of common stock less the sum of book value of common stock and balance sheet deferred taxes divided by the book value of assets.

${ }^{25}$ PP\&E to Total Assets Ratio is defined as the ratio of plant, property, and equipment to total assets.

${ }^{26}$ Cash to Total Assets Ratio is defined as the ratio of total cash to total assets.

${ }^{27}$ Market capitalization is taken from the most recently available annual financial statements in Compustat.

${ }^{28}$ Industry takeover intensity is defined as the percentage of firms in the 4-digit GICS industry that were taken over in calendar year 2009.
} 
annual meeting take place at later parts of the calendar year. We denote firms as belonging to the Treated-I group if they have a staggered board and their last annual meeting took place in June or a later month in the calendar year. ${ }^{29}$ We extend our analysis in Section 4.4 by examining alternative specifications with a cut-off month other than June.

We also examine groups of firms that can be hypothesized to be especially affected by the rulings because they satisfy one or more dimensions that make a control contest (and the magnitude of impediment to them) especially relevant. We define four dimensions that increase a firm's exposure to control contests: underperformance (up), high asset pledgibility (pl), small size (sm), and high industry takeover intensity (ti), and define the following four groups of "treated" firms:

- the Treated-II-up group - firms that are in the Treated-I group and have either a ROA below the industry median or a Tobin's Q below the industry median;

- the Treated-II-pl group - firms that are in the Treated-I group and have either a cash to total assets ratio above the industry median or a PP\&E to total assets ratio above the industry median;

- the Treated-II-sm group - firms that are in the Treated-I group and have a market capitalization below our sample's median; and

- the Treated-II-ti group - firms that are in the Treated-I group and belong to an industry with above median takeover intensity, defined as the percentage of firms in the 4-digit GICS industry that were acquired in 2009.

The Treated-II-up, Treated-II-pl, Treated-II-sm, and Treated-II-ti groups consist of subsets of Treated-I that each captures one of the four dimensions making a control contest more relevant. In addition, we define another treatment group composed of firms that are potentially most affected:

- the Treated-III group - firms that are in the Treated-I group and satisfy at least two of the four dimensions that magnify the relevance of control contests; in other words, the

\footnotetext{
${ }^{29}$ We choose June since it represents the upper half of our sample - the sample median meeting month is May. In Section 4.6 we test for the sensitivity of our primary results to changes to this meeting month cutoff.
} 
Treated-III group consists of firms that are in the Treated-I group and in at least two of the four Treated-II groups defined above.

\subsection{Announcement Returns and the Court Rulings}

We begin by studying the stock market returns experienced by affected firms during oneday and two-day windows following the announcements of the Chancery Court and the Supreme Court rulings. The Chancery Court ruling took place after the close of the stock market on Friday, October 8, 2010, and the first trading day following the ruling is thus Monday, October $11^{\text {th }}$, which was Columbus Day. Because trading volumes on Columbus Day are lower than usual $^{30}$ and because most of the substantive, in-depth media discussion of the Chancery Court ruling came out only on Monday, October 11 and Tuesday, October $12,{ }^{31}$ our primary focus will be on the two trading-day window ending at the close of the market on October $12^{\text {th }}$. Unlike the Chancery Court ruling, the Supreme Court's opinion was released during market trading hours, at 1:30PM on November $23^{\text {rd }}$. Given the short two-and-a half-hour window on the first trading day, we again focus primarily on the two-day trading window from the close of November $22^{\text {nd }}$ to the close of November $24^{\text {th }}$, but we also report results based on the one-day trading window from the close of November $22^{\text {nd }}$ to the close of November $23^{\text {rd }}$.

We focus on risk-adjusted excess returns as dependent variables to account for the possibility that differences in raw returns between groups of firms may reflect differences in risk characteristics. Following standard procedures, risk-adjusted excess returns are computed in two steps as follows. First, each firm's loadings on the Fama-French (1993) three factors and the Fama-French (1996) UMD momentum factor are estimated using the most recently available 120

\footnotetext{
${ }^{30}$ In the case of Columbus Day 2010, for example, the total dollar trading volume was $80 \%$ and $81.6 \%$ of the previous and the next trading day's total dollar trading volumes, respectively, and $79.3 \%$ and $75.8 \%$ of the two succeeding Mondays' total dollar trading volumes.

${ }^{31}$ See Amon, "Foreclosure Suits, BP, Airgas, UBS in Court News," Bloomberg, October 11, 2010; Gallardo, "Important Chancery Court Opinion for Corporations with Staggered Boards," HLS Corporate Governance Blog, October 11, 2010; Kelly, "Update: Airgas to Fight Court Ruling Over Annual Meeting," CNBC, October 11, 2010; McCarty and Kaskey, "Airgas to Appeal Delaware Ruling on Meeting Date in Air Products Dispute," Bloomberg, October 11, 2010; Quinn, "Airgas to Appeal," M \& A Law Prof Blog, October 11, 2010; Davidoff, "The Dwindling Options for Airgas," New York Times online, October 12, 2010; McCarty and Kaskey, "Airgas to appeal ruling on meeting," Philadelphia Inquirer, October 12, 2010.
} 
trading days' data ending on or prior to September $31^{\text {th }}$ of 2010 . That is, for each firm we obtain $\left(\hat{\beta}_{i, M}, \hat{\beta}_{i, S M B}, \hat{\beta}_{i, H M L}, \hat{\beta}_{i, U M D}\right)$ from the time-series regression:

$$
r_{t}=\propto_{1}+\beta_{M} \cdot M k t R f_{t}+\beta_{S M B} \cdot S M B_{t}+\beta_{H M L} \cdot H M L_{t}+\beta_{U M D} \cdot U M D_{t}+\varepsilon_{t} .
$$

We then obtain excess announcement window returns by taking the residuals from a crosssectional regression of raw announcement window returns on the estimated factor sensitivities. That is, for each firm, we obtain the fitted residual $\hat{\delta}_{i}$ from the cross-sectional regression:

$$
\operatorname{AnnRet}_{t}=\propto_{2}+\lambda_{M} \cdot \hat{\beta}_{i, M}+\lambda_{S M B} \cdot \hat{\beta}_{i, S M B}+\lambda_{H M L} \cdot \hat{\beta}_{i, H M L}+\lambda_{U M D} \cdot \hat{\beta}_{i, U M D}+\delta_{i} .
$$

We integrate the two events in our announcement returns analysis by pooling the observations from both events. Such an analysis has the advantage of increasing the sample size. It also enables testing hypotheses concerning the differences in magnitudes between the treatment effects of the two events.

An earlier work that pools events is that of Larcker, Ormazabal, and Taylor (2010). They study several events related to proxy access reform, with some operating to increase the likelihood of such a reform and some operating to reduce the likelihood of such a reform. Their analysis assumes that all the events had an effect of similar magnitude, though some with the opposite sign to others. In our initial analysis, we follow the approach of Larcker et al (2010) and makes the assumption that the Supreme Court decision, which overturned the Chancery Court ruling, was accompanied by announcement returns of similar magnitudes but of opposite sign to those of the Chancery Court ruling. We later on (Section 4.3) conduct an analysis without making this assumption and obtain results consistent with the two events having consequences of same magnitude but opposite signs.

Given the assumption used in this section that the events' consequences are of the same magnitude but opposite signs, we multiply the excess returns from the second ruling by negative one. We test for differences in announcement window returns between treated and non-treated firms in Table II by regressing the adjusted one- and two-day excess returns on each of the six treatment group indicators: Treated-I, Treated-II-up, Treated-II-pl, Treated-II-sm, Treated-II-ti, and Treated-III. In each specification we include an indicator for the second ruling date, Event-2, 
to account for possible differences in the mean returns between the two event dates. Panel A of Table II reports specifications estimated without 6-digit GICS industry fixed effects, and Panel B of Table II reports specifications with such fixed effects. All standard errors are clustered at the 6-digit GICS industry level.

In both Panels A and Panel B of Table II, we find strong evidence, particular with the two-day return window, that validating the Airgas bylaw and weakening the antitakeover force of staggered boards provides significantly positive returns for treated firms compared to nontreated firms. Over the two-day event window, we find that Treated-I firms on average outperformed non-treated firms by 48.3 basis points in the specification without fixed effects and by 44.5 basis points in the specification with fixed effects; both coefficients are significant at the $1 \%$ level.

Consistent with the rulings' impact depending on the presence of firm or industry characteristics that make control contests more relevant, the difference in the mean excess returns tends to be higher for the treated groups Treated-II-np, Treated-II-pl, Treated-II-sm, and Treated-II-ti than for the Treated-I group. Over the two day window, the treated groups TreatedII-np, Treated-II-pl, Treated-II-sm, and Treated-II-ti outperformed non-treated firms by 38.4 89.4 basis points when industry fixed effects are not included, and by 30.1 87.5 basis points when industry fixed effect are included. In six of eight specifications, the differences are statistically significant at the $1 \%$ level, and in all eight specifications the differences are statistically significant at the $10 \%$ (or lower) level.

The results are most pronounced, as hypothesized, for the Treated-III group of most affected firms. In the two-day trading window, firms in the Treated-III group outperformed nontreated firms by 83.3 basis points in the specification without industry fixed effects, and by 80.4 basis points in the specification with industry fixed effects, with the results being statistically significant at the $1 \%$ level in both specifications.

We note that any differences in mean announcement returns between the treated firms and the non-treated firms may be potentially attenuated by two factors: first, the extent to which the Chancery and Supreme Court rulings were viewed by the market as possible prior to the decisions; and, second, the extent to which the Chancery Court ruling was expected by the market to be reversed by the Delaware Supreme Court. Thus, whereas the identified positive 
returns to treated firm are significant, they are likely to understate the market's estimate of the value to treated firm of permitting Airgas-type bylaws. Furthermore, note that permitting Airgastype bylaws would have merely weakened rather than eliminated the antitakeover force of staggered boards: permitting such bylaws would have enabled shareholders to decrease, not eliminate, the extent to which staggered boards can delay the replacement of a majority of directors sought by a shareholder majority. Thus, whereas our results understate the market's estimate of the value to treated firms of permitting Airgas-type bylaws, this estimate in turn is likely to be lower than the market's estimate of the value of eliminating board classification.

\subsection{Announcement Returns and the Court Rulings - Differential Magnitudes}

In this section, we allow for the possibility that that the Supreme Court's reversal of the Chancery Court ruling might have an effect of a different magnitude than the Chancery Court ruling, and we test the assumption of equal magnitudes (but opposite sign) for the effects of the two events. To do so, we run a pooled OLS by regressing risk-adjusted one- and two-day announcement returns on a treated group indicator interacted with an indicator for the first event (Treated), a treated group indicator interacted with an indicator for the second event (DeTreated), and an indicator for the second event (Event-2). We report the results of the estimation in Table III. Panel A of Table III reports specifications without 6-digit GICS industry fixed effects and Panel B reports specifications with such fixed effects. As before, all standard errors are clustered at the 6-digit GICS industry level.

In Panels $\mathrm{A}$ and $\mathrm{B}$ of Table III, we find strong evidence consistent with the two rulings being associated with excess returns of similar magnitudes but in opposite signs. Focusing again on the two-day returns, Panel A of Table III indicates that, relative to non-treated firms, the excess returns to treated groups associated with the first ruling are positive in all six specifications, with statistical significance at the 5\% level for five of these specifications; the

excess two-day returns to treated groups associated with the second ruling are negative in all six specifications, with statistical significance at the 5\% level for three; and, finally, for all six specifications, an F-test fails to reject at the $10 \%$ level the null hypothesis that the sum of the differences in average excess returns for the first and second rulings (Treated + De-Treated) is zero. The results in Panel B of Table III, which include industry fixed effects, are consistent with 
the above results of Panel A. The excess two-day returns to treated groups associated with the first ruling are higher relative to non-treated firms for all six specifications, with statistical significance at the 5\% level for five; the excess two-day returns to treated groups associated with the second ruling are lower relative to non-treated firms for all six specifications, with statistical significance at the 5\% level for three; and, finally, in five of the six specifications, an F-tests fails to reject at the $5 \%$ level the null hypothesis that the sum of the differences in average excess returns for the first and second rulings (Treated + De-Treated) is zero.

Overall, the results in this Section are consistent with the hypothesis that weakening the antitakeover force of staggered boards is viewed by market participants as value-enhancing. Consistent with this hypothesis, the Chancery Court ruling was accompanied by positive relative returns to the companies whose staggered boards were made less insulating by the ruling, and the Supreme Court ruling, which eliminated this effect, was accompanied by negative relative returns to these companies.

We note again that any difference in returns between the treated and non-treated firms understates the market's estimate of the value-reduction produced by the antitakeover force of staggered boards for two reasons. First, as discussed earlier, prior to each of the rulings, the market likely attached a nontrivial probability to the ruling. Second, permitting Airgas-type bylaws would have merely weakened rather than eliminated the antitakeover force of staggered boards. Thus, as was the case earlier, our results in this section provide an under-estimate of the cost that market participants estimate to be generated by board classification.

\subsection{Simulation Exercise}

We now turn to another way of testing whether the observed patterns, of positive relative returns to treated firms from the Chancery Court ruling and negative relative returns to treated firms from the Supreme Court ruling, were produced by random sampling variation rather than the rulings. To test for this hypothesis, we conduct a simulation exercise over all non-event days from the first half of 2010 -- that is, from January $2^{\text {nd }}$ to June $30^{\text {th }}$.

In particular, for each pair of two-day windows in this period, we replicate the specifications in Panels A and B of Table II and Table III that use the Treated-III group indicator (reported in column (12)), and generate benchmark distributions of coefficients generated from 
non-event days. We then consider whether the observed Treated coefficients in Table II, and coefficients of Treated and De-Treated and Table III, are abnormal when compared to the simulated benchmark distribution.

To begin the exercise, we compute excess returns for each two-day window in a two-step procedure similar to that used in Tables II and III and in equations (1) and (2). First, we estimate each firm's Fama-French three factor and UMD momentum factor loadings using returns data from 140 to 20 trading days prior; second, we take the residuals from a cross-sectional regression of two-day raw returns on the estimated factor sensitivities. Once the two-day excess returns are generated for each day in the first half of 2010, we replicate the pooled regression results of Tables II and III using the Treated-III group indicator for each pair of two-day windows in the period.

In particular, to replicate the specifications of Table II over non-event days, we multiply the returns from the latter of the two non-event days by negative one, and we regress the adjusted returns on the Treated-III group indicator and an indicator for the second event date. To replicate the specifications of Table III, we run a pooled OLS by regressing risk-adjusted two-day returns on the Treated-III group indicator interacted with an indicator for the first event (Treated-III), the Treated-III group indicator interacted with an indicator for the second event (De-Treated-III), and an indicator for the second event.

Figure I displays the non-parametric Epanechnikov kernel density estimates of the simulated non-event Treated-III coefficients, generated following the constrained model of Table II. The dotted vertical line on each graph represents the location of our observed coefficients. We see from the figure that the simulated coefficients are approximately normally distributed and centered around 0. Moreover, our observed coefficients of 83.3 and 80.4 in the no fixed effects and fixed effects specifications of Table III are abnormally large when compared to the simulated distributions. Specifically, in Panel A of Table IV, which reports the univariate distributional summaries of the simulated coefficients, rows [1] and [2] indicate that our observed coefficients lie outside the $99^{\text {th }}$ percentiles of the distribution of simulated coefficients. In fact, only less than $0.5 \%$ of coefficients simulated based on the non-fixed-effects model in Panel A of Table III are larger than our observed coefficient of 83.3; and less than $0.2 \%$ of 
coefficients simulated based on the fixed-effects model in Panel B of Table III are larger than our observed coefficient of 80.4.

Figure II displays the non-parametric kernel bivariate density estimates of the simulated Treated and De-Treated coefficients, generated following the unconstrained model of Table III. The white arrow on each graph indicates the location of our observed pair of coefficients. As we see in Figure II and in rows [3]-[6] of Panel A of Table IV, the simulated coefficients are approximately bivariate normal and centered around $(0,0)$. In comparison to this distribution, our observed Treated and De-Treated coefficients - of 86.5 and -80.0 in the no fixed effects model and 95.4 and -71.0 in the fixed effects model of Table III - are abnormally large in magnitude.

Table IV Panel B, which reports bivariate distributional summaries of the simulated Treated and De-Treated coefficients, shows that less than $0.1 \%$ of the simulated coefficients using the no-fixed-effects model are as large in magnitude (that is, having a Treated coefficient that is no smaller than the observed and a De-Treated coefficient that is no larger than the observed) as those of Table III Panel A. In the fixed effect model, less than $0.2 \%$ of the simulated coefficients using the fixed effects model are as extreme as those in Table III Panel B.

In summary, our simulation results show that the treatment effects on the Treated-III group of firms observed in Tables II and III are highly unlikely to have arisen from random sampling variation. In each specification considered, we can reject the null hypothesis that the true mean treatment effects are 0 at the $0.5 \%$ or lower significance level.

\subsection{Different Meeting Date Cut-offs}

In our primary empirical tests above, we defined treated firms on the basis of having a prior annual meeting date taking place in June or a later month in the calendar year. This threshold represents the upper half of the sample distribution and approximately represents the latter half of the year. In this section, we examine whether our results are robust to using different meeting month cutoffs and find that they are.

To test robustness to using different meeting month cutoffs, we define nine versions of Treated-III. As before, the firms in the Treated-III group all have a staggered board and satisfy at least two of the four dimensions of firm or industry characteristics that make control contests especially relevant: underperformance, high asset pledgibility, small size, and high industry 
takeover intensity. In contrast to before, where all Treated-III firms' annual meetings took place in or after June in the calendar year, we now have versions with a different cut-off meeting month. In particular, the nine versions of the Treated-III group we consider below are based on different cut-off months from February through October. ${ }^{32}$

Our robustness tests employ the pooling specifications of Panels A and B of Table II, using two-day excess returns as dependent variables. Table $\mathrm{V}$ reports the excess returns of Treated-III (relative to non-Treated-III) firms based on the nine variations of the annual meeting month cutoffs. Panel A of this Table V does not include industry fixed effects, and Panel B of Table $\mathrm{V}$ includes such fixed effects.

Both Panel A and Panel B of Table V display the same pattern: as we increase the cutoff month from February to October, the difference in the average two-day excess returns between Treated-III and non-Treated-III firms trends upwards; indeed, with the exceptions of August and October, the increase is monotonic. In the no-fixed effects specifications of Panel A, the TreatedIII coefficient grows from 35.1 basis points using a February cutoff to 83.3 basis points using a June cutoff to 84.7 basis points using an October cutoff. Consistent with this pattern, in the fixed-effects specifications of Panel B, the Treated-III coefficient grows from 34.7 basis points using a February cutoff to 80.4 basis points using a June cutoff to 88.7 basis points using an October cutoff.

In addition, Panel $\mathrm{C}$ of Table $\mathrm{V}$ reports a specification in which we regress the two-day risk-adjusted returns on a Treated-III indicator (but without the June cutoff requirement), the month of last annual meeting, an interaction of the treatment indicator with the month of last annual meeting, and an indicator for the second event date. In both the no-fixed-effects and fixed-effects specifications in Panel $\mathrm{C}$, the interaction terms are positive and statistically significant at the 5\% level. These results are consistent with the mean difference in announcement returns between treated and non-treated firms being larger in magnitude among those firms whose annual meeting took place later in the year.

In summary, the patterns documented in Table $\mathrm{V}$ are consistent with the rulings (and the Airgas bylaw whose validity was at stake) having the greatest potential impact among firms that

\footnotetext{
${ }^{32}$ Using a cut-off meeting month of November or December leaves too few firms in the treated group to enable testing.
} 
have annual meeting months later in the calendar year - that is, firms in which the Airgas bylaw could be used to significantly reduce the tenure of directors whose removal would be otherwise delayed by a staggered board. By showing that the magnitude of the identified effects in Table II increases as the cutoff month increases, these robustness tests reinforce our earlier conclusions concerning the Delaware Chancery and Supreme Court rulings' effects.

\section{Conclusion}

This paper has sought to contribute to understanding the sources of the well-documented correlation between governance provisions insulating directors from removal, in particular staggered boards, and lower firm value. We have used a natural experiment - a recent Delaware Chancery Court ruling enabling shareholders to weaken the extent to which staggered boards insulate directors from removal and the subsequent reversal of this ruling by the Delaware Supreme Court - to identify how market participants in the aggregate view the effect of staggered boards on firm value. We find evidence consistent with market participants' viewing staggered boards as bringing about a reduction in firm value.

Our findings are consistent with the ongoing debate on staggered boards and the efforts of institutional investors to reduce the large number of companies that still have staggered boards. Our findings are consistent with policies adopted by many institutional investors in favor of proposals to de-stagger boards. Our findings are also consistent with the view that the ongoing process of dismantling staggered boards, encouraged by institutional investors, could be expected to contribute to increasing shareholder wealth. 


\section{References}

Baghat, Sanjai, and Roberta Romano (2002). "Event Studies and the Law: Part II: Empirical Studies of Corporate Law." American Law and Economics Review 4: 380-423.

Bates, Thomas W., David A. Becher, and Michael L. Lemmon (2008). "Board Classification and Managerial Entrenchment: Evidence from the Market for Corporate Control." Journal of Financial Economics 87: 656- 677.

Bebchuk, Lucian A., John C. Coates, and Guhan Subramanian (2002a). "The Powerful Antitakeover Force of Staggered Boards: Theory, Evidence, and Policy." Stanford Law Review 54: 887-951.

Bebchuk, Lucian A., John C. Coates, and Guhan Subramanian (2002b). "The Powerful Antitakeover Force of Staggered Boards: Theory, Evidence, and Policy: A Reply and extension" Stanford Law Review.

Bebchuk, Lucian A. and Alma Cohen (2005). "The Cost of Entrenched Boards." Journal of Financial Economics 78: 409-433.

Bebchuk, Lucian A., Alma Cohen, and Allen Ferrell (2009). "What Matters in Corporate Governance?" Review of Financial Studies 22: 783-785.

Bebchuk, Lucian A., Alma Cohen, and Charles Wang (2010). "Golden Parachutes and the Wealth of Shareholders." Discussion Paper No. 683, John M. Olin Center for Law, Economics, and Business, Harvard Law School.

Becker, Bo, Daniel Bergstresser, and Guhan Subramanian (2010). "Does Shareholder Proxy Access Improve Firm Value? Evidence from the Business Roundtable Challenge.” Working Paper.

Bernard, Victor, and Jacob K. Thomas (1989). "Post-Earnings Announcement Drift: Delayed Price Response or Risk Premium?” Journal of Accounting Research, Supplement XXVII: 136.

Bhojraj, Sanjeev, Charles M.C. Lee, and Derek K. Oler (2003). "What's My Line? A Comparison of Industry Classification Schemes for Capital Market Research." Journal of Accounting Research 41:745-774.

Binder, John J. (1985). "Measuring the Effects of Regulation with Stock Price Data." RAND Journal of Economics 16: 167-183. 
Chhaochharia, Vidhi, and Yaniv Grinstein (2007). "Corporate Governance and Firm Value: The Impact of the 2002 Governance Rules." Journal of Finance 62: 1789-1825.

Coates, John (2000). "Takeover Defenses in the Shadow of the Pill: A Critique of the Scientific Evidence.” Texas Law Review 79: 271-382.

DellaVigna, Stefano and Joshua Pollet (2009). "Investor Inattention and Friday Earnings Announcements." Journal of Finance 64: 709-749.

Faleye, Olubunmi (2007). "Classified Boards, Firm Value, and Managerial Entrenchment." Journal of Financial Economics 83: 501-529.

Fama, Eugene and Kenneth R. French (1993). "Common Risk Factors in the Returns on Bonds and Stocks." Journal of Financial Economics 33: 3-53.

Fama, Eugene and Kenneth R. French (1996). "Multifactor Explanations of Asset Pricing Anomalies." Journal of Finance 51: 55-87.

Gompers, Paul A., Joy L. Ishii, and Andrew Metrick (2003). "Corporate Governance and Equity Prices." Quarterly Journal of Economics 118(1):107-155.

Guo, Re-Jin, Timothy A. Kruse, and Tom Nohel (2008). "Undoing the Powerful Anti-Takeover Force of Staggered Boards." Journal of Corporate Finance 14: 274 - 288.

Hochberg, Yael V., Paola Sapienza, and Annette Vissing-Jorgensen (2009). "A Lobbying Approach to Evaluating the Sarbanes-Oxley Act of 2002." Journal of Accounting Research 47: 519-583.

Karpoff, Jonathan M. and Paul H. Malatesta (1989). "The Wealth Effects of Second-Generation State Takeover Legislation.” Journal of Financial Economics 25: 291-322.

Larcker, David F., Gaizka Ormazabal, and Daniel J. Taylor (2010). "The Market Reaction to Corporate Governance Regulation." Journal of Financial Economics. Forthcoming. MacKinlay, A. Craig (1997). "Event Studies in Economics and Finance," Journal of Economic Literature 35: 13-39.

Schwert, William (1981). "Using Financial Data to Measure Effects of Regulation.” Journal of Law and Economics 121: 121-158. 


\section{Figure I}

Figure I displays the non-parametric Epanechnikov kernel density estimates of Treated-III coefficients (parallel to column 12 of Panels A and B of Table II), simulated over all unique pairs of days over the non-event window of January $2^{\text {nd }}$ to June $30^{\text {th }}$ of 2010. Non-event coefficients are obtained as follows: for each pair of trading days, multiply the second event day's two-day riskadjusted returns by negative one and regress these returns on the Treated-III indicator, described in Section 4.1, and an indicator for the second event date. The left hand side (right hand side) figure plots the distribution of coefficients estimated based on the no-fixed-effects (fixed-effects) model of Panel A (Panel B) in Table II. The dashed vertical lines indicate the location of the observed corresponding coefficients in column (12) of Table II Panels A and B.

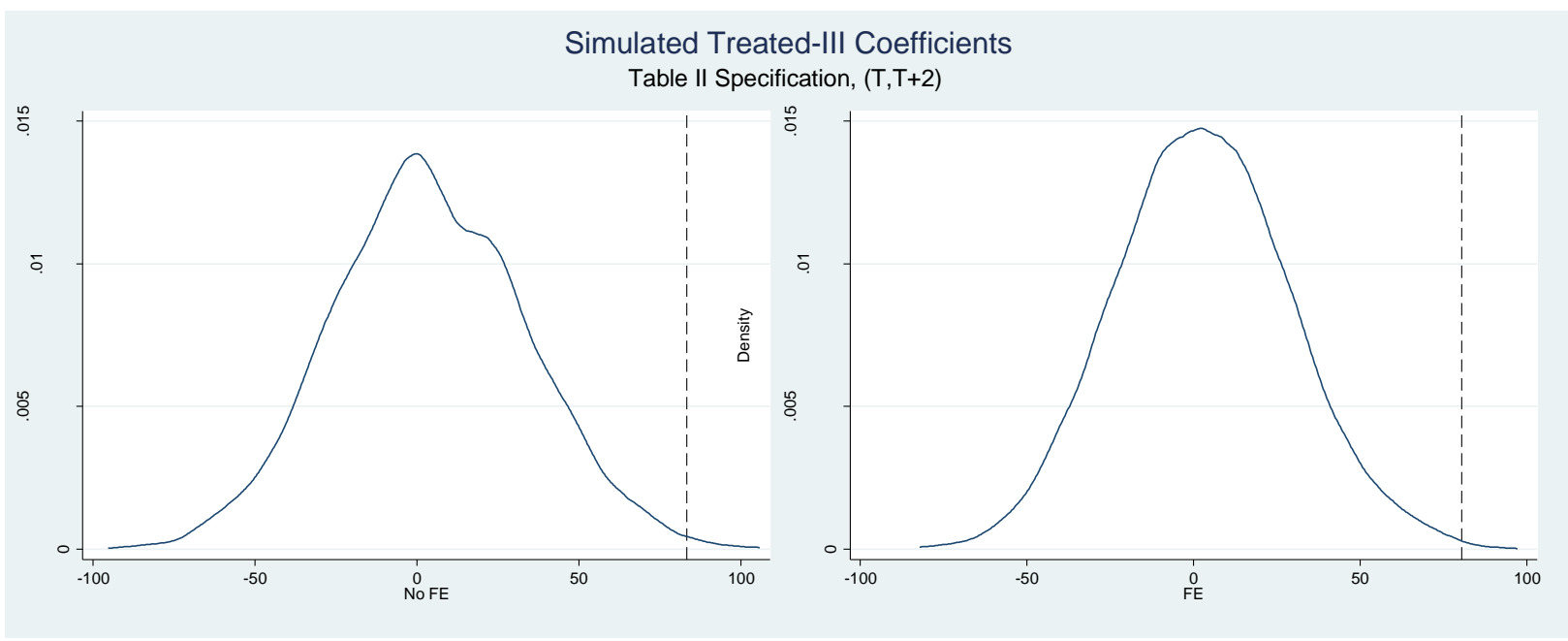




\section{Figure II}

Figure I displays the non-parametric kernel bivariate density estimates of non-event Treated and De-Treated coefficients, simulated based on the no-fixed-effects and fixed-effects specifications in column (12) of Panels A and B in Table III, and simulated over all unique pairs of days over the non-event window of January $2^{\text {nd }}$ to June $30^{\text {th }}$ of 2010 . Non-event coefficients are obtained as follows: for each pair of trading days, create Treated and De-Treated following Table III specifications and using the Treated-III group of firms, and regress risk-adjusted two-day returns on Treated, De-Treated, and an indicator for the second event date. The left hand side (right hand side) figure plots the bivariate distribution of coefficients estimated based on the no-fixed-effects (fixed-effects) model of Panel A (Panel B) in Table III. The arrow lines indicate the location of the observed corresponding coefficients in column (12) Table III Panels A and B.
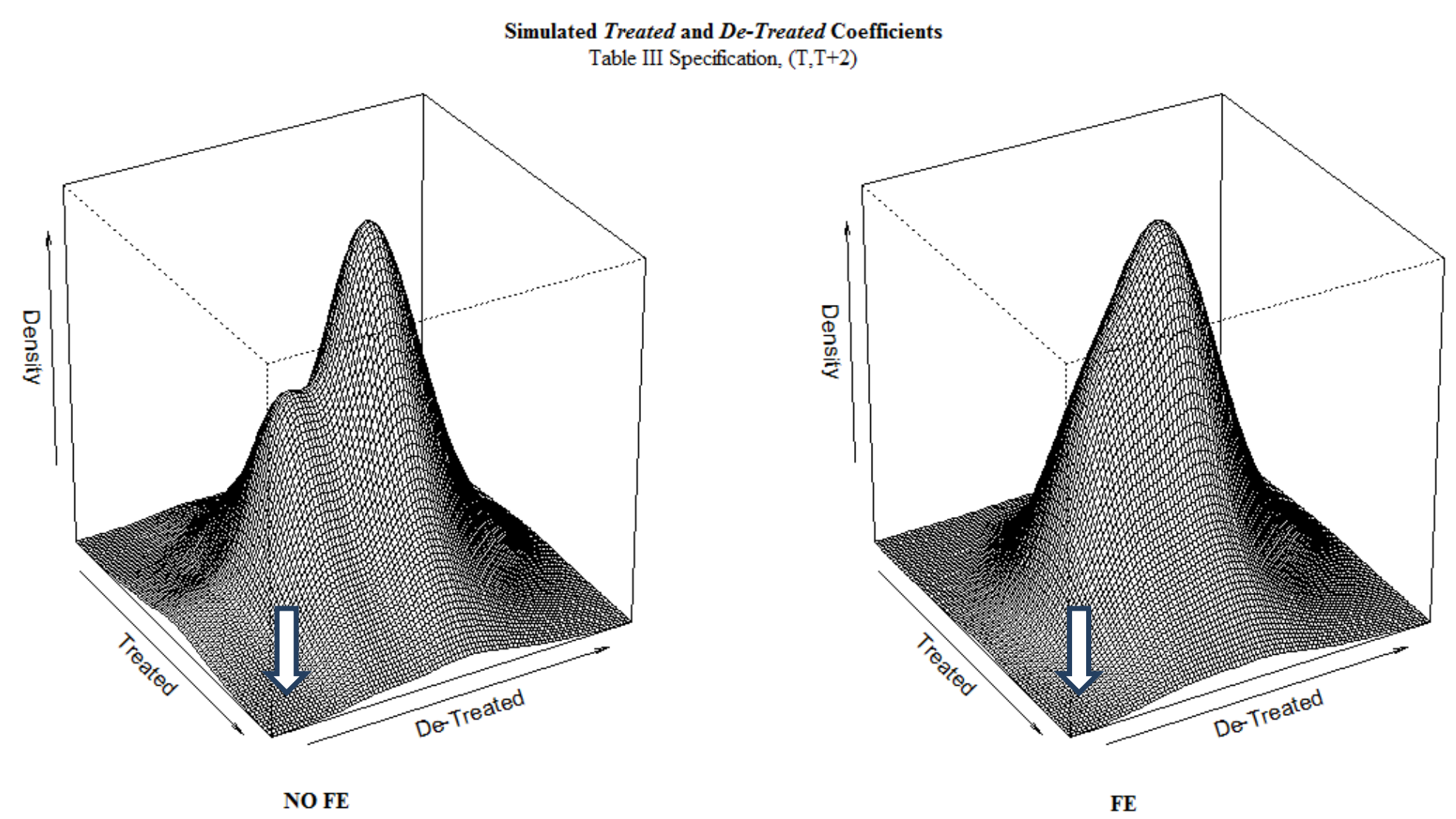

FE 


\section{Table I: Summary Statistics}

Table I reports summary statistics for the sample used in the paper, for firms with and without staggered boards and for all firms. Our base dataset comes from Shark Repellent, and consists of all U.S. based firms listed on NYSE, NYSE AMEX, NYSE ARCA, NASDAQ, or NASDAQ Capital Market, and excludes all dual-class firms, all real estate investment trusts (REITS, SIC = 6798), and all firms with insider equity ownership exceeding 50\%. We obtain October and November stock returns from Datastream, historical returns from CRSP, and GICS and annual financial statement information from Compustat, resulting in a final sample of 2,633 observations. Meeting month is defined to be the month in which the last annual shareholders' meeting took place; Ind-Adjusted PPE/Assets is defined to be the plant, property, and equipment to total assets ratio less the GICS6 industry median; Ind-Adjusted Cash/Assets is defined to be the cash to total assets ratio less the GICS6 industry median; Ind-adjusted ROA is defined to be ROA less the GICS6 industry median, where ROA is defined as operating income divided by book value of assets from end of previous fiscal year; industry-adjusted Q is defined to be Tobin's Q less the GICS6 industry median, where Q is defined as market value of assets divided by the book value of assets plus the market value of common stock less the sum of book value of common stock and balance sheet deferred taxes; market capitalization is taken from the most recently available annual financial statements; and takeover intensity is defined to be the proportion of firms in the GICS4 industry in calendar year 2009 that were acquired.

Panel A: Firms with a Staggered Board

\begin{tabular}{lccccc}
\hline \hline Variables & Min & Median & Mean & Max & StdDev \\
\hline $\mathbf{N = 1 , 2 4 0 )}$ & & & & & \\
Meeting Month & 1 & 5 & 5.394 & 12 & 2.044 \\
Ind-Adjusted PPE/Assets & -0.4229 & 0.0000 & 0.0146 & 0.4981 & 0.1306 \\
Ind-Adjusted Cash/Assets & -3.9660 & 0.0332 & -0.1518 & 2.0110 & 1.1191 \\
Ind-Adjusted ROA & -0.6441 & 0.0072 & 0.0047 & 0.5190 & 0.1519 \\
Ind-Adjusted Tobin's Q & -1.5310 & 0.0001 & 0.2478 & 4.9403 & 1.0436 \\
Market cap (\$Mil) & 1 & 504 & 1,958 & 80,453 & 4,693 \\
Takeover Intensity & 0.0000 & 0.0443 & 0.0518 & 0.0954 & 0.0237 \\
\hline \hline
\end{tabular}

Panel B: Firms without a Staggered Board

\begin{tabular}{|c|c|c|c|c|c|}
\hline Variables & Min & Median & Mean & Max & StdDev \\
\hline \multicolumn{6}{|l|}{$(\mathrm{N}=1,393)$} \\
\hline Meeting Month & 1 & 5 & 5.6698 & 12 & 2.1707 \\
\hline Ind-Adjusted PPE/Assets & -0.4229 & 0.0000 & 0.0172 & 0.4981 & 0.1415 \\
\hline Ind-Adjusted Cash/Assets & -3.9660 & 0.0237 & -0.1046 & 2.0110 & 1.0491 \\
\hline Ind-Adjusted ROA & -0.6441 & 0.0083 & 0.0080 & 0.5190 & 0.1589 \\
\hline Ind-Adjusted Tobin's Q & -1.5310 & 0.0080 & 0.2523 & 4.9403 & 1.0047 \\
\hline Market cap (\$Mil) & 1 & 728 & 6,566 & 328,676 & 22,979 \\
\hline Takeover Intensity & 0.0000 & 0.0490 & 0.0506 & 0.0954 & 0.0231 \\
\hline \multicolumn{6}{|l|}{ Panel C: All Firms } \\
\hline Variables & Min & Median & Mean & Max & StdDev \\
\hline \multicolumn{6}{|l|}{$(\mathrm{N}=2,633)$} \\
\hline Meeting Month & 1 & 5 & 5.540 & 12 & 2.116 \\
\hline Ind-Adjusted PPE/Assets & -0.4229 & 0.0000 & 0.0160 & 0.4981 & 0.1365 \\
\hline Ind-Adjusted Cash/Assets & -3.9660 & 0.0259 & -0.1268 & 2.0110 & 1.0827 \\
\hline Ind-Adjusted ROA & -0.6441 & 0.0083 & 0.0080 & 0.5190 & 0.1589 \\
\hline Ind-Adjusted Tobin's Q & -1.5310 & 0.0044 & 0.2502 & 4.9403 & 1.0231 \\
\hline Market cap (\$Mil) & 1 & 600 & 4,399 & 328,676 & 17,184 \\
\hline Takeover Intensity & 0.0000 & 0.0490 & 0.0512 & 0.0954 & 0.0234 \\
\hline
\end{tabular}


Table II: Announcement Returns - Assuming Opposite Effects of the Two Events

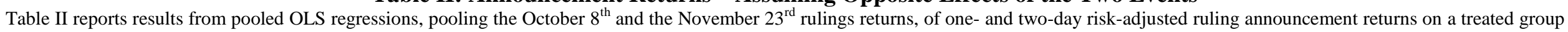

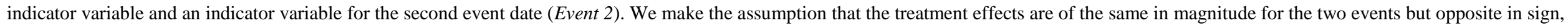

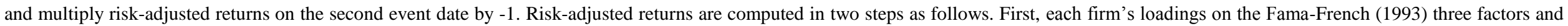

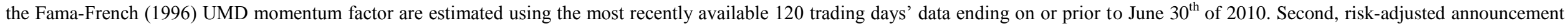

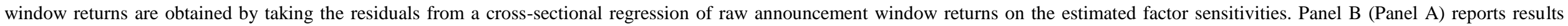

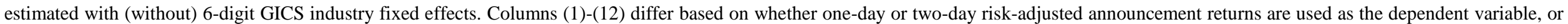

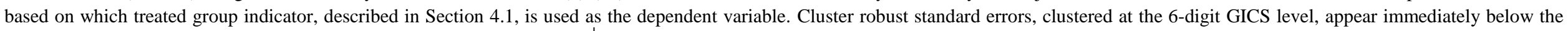
coefficient estimate in parentheses. Levels of significance are indicated by ${ }^{+}, * * *$, and $* * *$ for $15 \%, 10 \%, 5 \%$, and $1 \%$, respectively.

Panel A: No Industry Fixed Effects

\begin{tabular}{|c|c|c|c|c|c|c|c|c|c|c|c|c|}
\hline & (1) & (2) & (3) & (4) & (5) & (6) & (7) & (8) & (9) & (10) & (11) & (12) \\
\hline & \multicolumn{2}{|c|}{ Treated-I } & \multicolumn{2}{|c|}{ Treated-II-up } & \multicolumn{2}{|c|}{ Treated-II-pl } & \multicolumn{2}{|c|}{ Treated-II-sm } & \multicolumn{2}{|c|}{ Treated-II-ti } & \multicolumn{2}{|c|}{ Treated-III } \\
\hline & 1-Day & 2-Day & 1-Day & 2-Day & 1-Day & 2-Day & 1-Day & 2-Day & 1-Day & 2-Day & 1-Day & 2-Day \\
\hline Treated & $\begin{array}{c}7.231 \\
(10.04)\end{array}$ & $\begin{array}{c}48.307 * * * \\
(14.83)\end{array}$ & $\begin{array}{c}22.948^{+} \\
(14.33)\end{array}$ & $\begin{array}{c}89.398 * * * \\
(23.11)\end{array}$ & $\begin{array}{c}9.516 \\
(10.26)\end{array}$ & $\begin{array}{c}55.800 * * * \\
(17.31)\end{array}$ & $\begin{array}{l}20.526 \\
(15.87)\end{array}$ & $\begin{array}{c}75.961 * * * \\
(27.09)\end{array}$ & $\begin{array}{l}1.702 \\
(9.71)\end{array}$ & $\begin{array}{c}38.404 * * \\
(15.75)\end{array}$ & $\begin{array}{c}19.952 \\
(14.82)\end{array}$ & $\begin{array}{c}83.259 \text { *** } \\
(25.96)\end{array}$ \\
\hline Event 2 & $\begin{array}{c}2.683 \\
(14.72)\end{array}$ & $\begin{array}{c}-2.823 \\
(18.22)\end{array}$ & $\begin{array}{c}2.682 \\
(14.72)\end{array}$ & $\begin{array}{c}-2.824 \\
(18.22)\end{array}$ & $\begin{array}{c}2.683 \\
(14.72)\end{array}$ & $\begin{array}{l}-2.823 \\
(18.22)\end{array}$ & $\begin{array}{c}2.682 \\
(14.72)\end{array}$ & $\begin{array}{l}-2.823 \\
(18.22)\end{array}$ & $\begin{array}{c}2.683 \\
(14.72)\end{array}$ & $\begin{array}{l}-2.822 \\
(18.22)\end{array}$ & $\begin{array}{c}2.682 \\
(14.72)\end{array}$ & $\begin{array}{c}-2.824 \\
(18.22)\end{array}$ \\
\hline Cons & $\begin{array}{c}-6.074 \\
(9.32)\end{array}$ & $\begin{array}{l}-8.463 \\
(13.47)\end{array}$ & $\begin{array}{c}-7.274 \\
(9.05)\end{array}$ & $\begin{array}{c}-10.048 \\
(13.10)\end{array}$ & $\begin{array}{r}-6.208 \\
(9.42) \\
\end{array}$ & $\begin{array}{c}-8.341 \\
(13.43)\end{array}$ & $\begin{array}{r}-6.766 \\
(9.15) \\
\end{array}$ & $\begin{array}{l}-7.715 \\
(13.35)\end{array}$ & $\begin{array}{r}-5.139 \\
(9.29) \\
\end{array}$ & $\begin{array}{c}-4.974 \\
(13.88)\end{array}$ & $\begin{array}{c}-6.806 \\
(9.13)\end{array}$ & $\begin{array}{l}-8.735 \\
(13.32)\end{array}$ \\
\hline Observations & 5,265 & 5,265 & 5,265 & 5,265 & 5,265 & 5,265 & 5,265 & 5,265 & 5,265 & 5,265 & 5,265 & 5,265 \\
\hline Adj. Rsq & 0.000 & 0.002 & 0.000 & 0.005 & 0.000 & 0.002 & 0.000 & 0.003 & 0.000 & 0.001 & 0.000 & 0.004 \\
\hline
\end{tabular}

Panel B: Industry Fixed Effects

\begin{tabular}{|c|c|c|c|c|c|c|c|c|c|c|c|c|}
\hline & (1) & (2) & (3) & (4) & (5) & (6) & (7) & (8) & (9) & (10) & (11) & (12) \\
\hline & \multicolumn{2}{|c|}{ Treated-I } & \multicolumn{2}{|c|}{ Treated-II-up } & \multicolumn{2}{|c|}{ Treated-II-pl } & \multicolumn{2}{|c|}{ Treated-II-sm } & \multicolumn{2}{|c|}{ Treated-II-ti } & \multicolumn{2}{|c|}{ Treated-III } \\
\hline & 1-Day & 2-Day & 1-Day & 2-Day & 1-Day & 2-Day & 1-Day & 2-Day & 1-Day & 2-Day & 1-Day & 2-Day \\
\hline Treated & $\begin{array}{l}10.466 \\
(10.77)\end{array}$ & $\begin{array}{c}44.506 * * * \\
(15.81)\end{array}$ & $\begin{array}{c}26.693 * \\
(14.39)\end{array}$ & $\begin{array}{c}87.522 * * * \\
(23.54)\end{array}$ & $\begin{array}{l}12.365 \\
(10.80)\end{array}$ & $\begin{array}{c}49.282^{* * *} \\
(17.91)\end{array}$ & $\begin{array}{c}27.782 * \\
(16.12)\end{array}$ & $\begin{array}{c}75.232 * * * \\
(27.39)\end{array}$ & $\begin{array}{l}6.625 \\
(9.62)\end{array}$ & $\begin{array}{c}30.099 * \\
(15.25)\end{array}$ & $\begin{array}{c}25.314 * \\
(14.74)\end{array}$ & $\begin{array}{c}80.439 * * * \\
(26.12)\end{array}$ \\
\hline Event 2 & $\begin{array}{c}2.686 \\
(14.82)\end{array}$ & $\begin{array}{l}-2.809 \\
(18.34)\end{array}$ & $\begin{array}{c}2.686 \\
(14.82)\end{array}$ & $\begin{array}{l}-2.809 \\
(18.34)\end{array}$ & $\begin{array}{c}2.686 \\
(14.82)\end{array}$ & $\begin{array}{l}-2.809 \\
(18.34)\end{array}$ & $\begin{array}{c}2.686 \\
(14.82)\end{array}$ & $\begin{array}{l}-2.808 \\
(18.34)\end{array}$ & $\begin{array}{c}2.687 \\
(14.82)\end{array}$ & $\begin{array}{c}-2.808 \\
(18.34)\end{array}$ & $\begin{array}{c}2.686 \\
(14.82)\end{array}$ & $\begin{array}{l}-2.809 \\
(18.34)\end{array}$ \\
\hline Cons & $\begin{array}{l}-6.572 \\
(7.17) \\
\end{array}$ & $\begin{array}{l}-7.887 \\
(8.89) \\
\end{array}$ & $\begin{array}{r}-7.653 \\
(7.08) \\
\end{array}$ & $\begin{array}{r}-9.867 \\
(8.65) \\
\end{array}$ & $\begin{array}{l}-6.582 \\
(7.30) \\
\end{array}$ & $\begin{array}{l}-7.497 \\
(8.96) \\
\end{array}$ & $\begin{array}{c}-7.404 \\
(7.16) \\
\end{array}$ & $\begin{array}{r}-7.659 \\
(8.86) \\
\end{array}$ & $\begin{array}{l}-5.643 \\
(7.38) \\
\end{array}$ & $\begin{array}{l}-4.133 \\
(9.44) \\
\end{array}$ & $\begin{array}{l}-7.303 \\
(7.15) \\
\end{array}$ & $\begin{array}{l}-8.482 \\
(8.81) \\
\end{array}$ \\
\hline Observations & 5,265 & 5,265 & 5,265 & 5,265 & 5,265 & 5,265 & 5,265 & 5,265 & 5,265 & 5,265 & 5,265 & 5,265 \\
\hline Adj. Rsq & 0.004 & 0.005 & 0.004 & 0.007 & 0.004 & 0.005 & 0.004 & 0.006 & 0.003 & 0.003 & 0.004 & 0.006 \\
\hline
\end{tabular}


Table III: Announcement Returns - Allowing for Differential Magnitudes

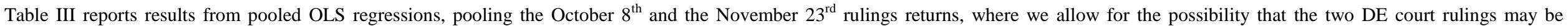

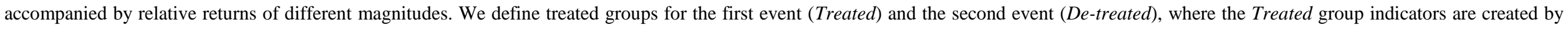

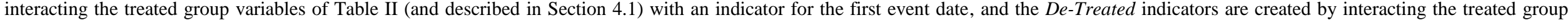

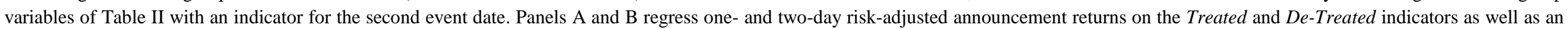

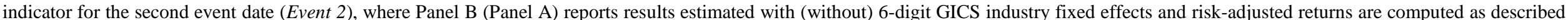

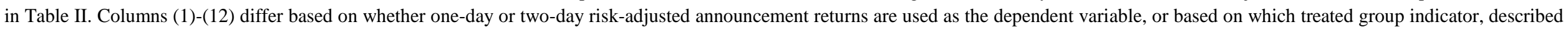

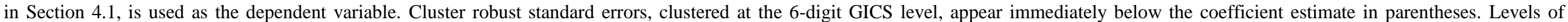
significance are indicated by ${ }^{+}, *, * *$, and $* * *$ for $15 \%, 10 \%, 5 \%$, and $1 \%$, respectively.

Panel A: No Industry Fixed Effects

\begin{tabular}{|c|c|c|c|c|c|c|c|c|c|c|c|c|}
\hline & (1) & (2) & (3) & (4) & (5) & (6) & (7) & (8) & (9) & (10) & (11) & (12) \\
\hline & \multicolumn{2}{|c|}{ Treated-I } & \multicolumn{2}{|c|}{ Treated-II-up } & \multicolumn{2}{|c|}{ Treated-II-pl } & \multicolumn{2}{|c|}{ Treated-II-sm } & \multicolumn{2}{|c|}{ Treated-II-ti } & \multicolumn{2}{|c|}{ Treated-III } \\
\hline & 1-Day & 2-Day & 1-Day & 2-Day & 1-Day & 2-Day & 1-Day & 2-Day & 1-Day & 2-Day & 1-Day & 2-Day \\
\hline Treated & $\begin{array}{l}28.768^{+} \\
(18.67)\end{array}$ & $\begin{array}{c}73.206 * * * \\
(24.15)\end{array}$ & $\begin{array}{l}32.493 \\
(22.81)\end{array}$ & $\begin{array}{c}97.572 * * * \\
(35.71)\end{array}$ & $\begin{array}{l}33.440^{+} \\
(20.58)\end{array}$ & $\begin{array}{c}87.494 * * * \\
(28.94)\end{array}$ & $\begin{array}{l}29.899 \\
(26.48)\end{array}$ & $\begin{array}{c}79.136^{* * *} \\
(39.44)\end{array}$ & $\begin{array}{l}10.097 \\
(20.28)\end{array}$ & $\begin{array}{l}41.658^{+} \\
(25.40)\end{array}$ & $\begin{array}{l}27.568 \\
(24.00)\end{array}$ & $\begin{array}{c}86.506 * * \\
(37.54)\end{array}$ \\
\hline De-Treated & $\begin{array}{l}14.307 \\
(12.64)\end{array}$ & $\begin{array}{l}-23.406 \\
(21.45)\end{array}$ & $\begin{array}{l}-13.403 \\
(14.89)\end{array}$ & $\begin{array}{c}-81.224 * * * \\
(26.57)\end{array}$ & $\begin{array}{l}14.410 \\
(14.41)\end{array}$ & $\begin{array}{l}-24.104 \\
(23.76)\end{array}$ & $\begin{array}{l}-11.153 \\
(17.64)\end{array}$ & $\begin{array}{c}-72.785 * * * \\
(26.74)\end{array}$ & $\begin{array}{c}6.692 \\
(18.64)\end{array}$ & $\begin{array}{l}-35.149 \\
(30.36)\end{array}$ & $\begin{array}{l}-12.336 \\
(15.72)\end{array}$ & $\begin{array}{c}-80.012 * * * \\
(27.84)\end{array}$ \\
\hline Event 2 & $\begin{array}{c}9.464 \\
(11.30)\end{array}$ & $\begin{array}{l}19.747 \\
(15.28)\end{array}$ & $\begin{array}{l}11.866 \\
(10.81)\end{array}$ & $\begin{array}{l}22.920^{+} \\
(14.38)\end{array}$ & $\begin{array}{c}9.732 \\
(11.37)\end{array}$ & $\begin{array}{l}19.504 \\
(15.11)\end{array}$ & $\begin{array}{l}10.848 \\
(10.89)\end{array}$ & $\begin{array}{l}18.253 \\
(14.84)\end{array}$ & $\begin{array}{c}7.594 \\
(10.76)\end{array}$ & $\begin{array}{l}12.771 \\
(15.13)\end{array}$ & $\begin{array}{l}10.929 \\
(10.96)\end{array}$ & $\begin{array}{l}20.293 \\
(14.67)\end{array}$ \\
\hline Cons & $\begin{array}{l}-9.379 \\
(9.42)\end{array}$ & $\begin{array}{l}-12.283 \\
(13.12)\end{array}$ & $\begin{array}{c}(8.235) \\
(9.32)\end{array}$ & $\begin{array}{c}(10.871) \\
(13.35)\end{array}$ & $\begin{array}{l}-9.334 \\
(9.46)\end{array}$ & $\begin{array}{c}-12.482 \\
(13.06)\end{array}$ & $\begin{array}{r}-7.588 \\
(9.35)\end{array}$ & $\begin{array}{l}-7.994 \\
(13.54)\end{array}$ & $\begin{array}{c}-5.996 \\
(9.25)\end{array}$ & $\begin{array}{l}-5.307 \\
(13.73)\end{array}$ & $\begin{array}{r}-7.509 \\
(9.26)\end{array}$ & $\begin{array}{l}-9.034 \\
(13.60)\end{array}$ \\
\hline Observations & 5,265 & 5,265 & 5,265 & 5,265 & 5,265 & 5,265 & 5,265 & 5,265 & 5,265 & 5,265 & 5,265 & 5,265 \\
\hline F-Stat & 3.027 & 2.055 & 0.550 & 0.146 & 2.722 & 2.503 & 0.345 & 0.025 & 0.247 & 0.020 & 0.302 & 0.025 \\
\hline P-Val & 0.087 & 0.156 & 0.461 & 0.703 & 0.104 & 0.118 & 0.559 & 0.875 & 0.621 & 0.889 & 0.584 & 0.874 \\
\hline Adj. Rsq & 0.000 & 0.002 & 0.000 & 0.005 & 0.000 & 0.003 & 0.000 & 0.003 & 0.000 & 0.000 & 0.000 & 0.000 \\
\hline
\end{tabular}




\section{Table III: Announcement Returns -- Allowing for Differential Magnitudes (Cont'd)}

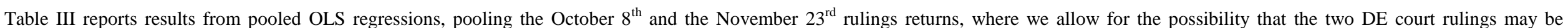

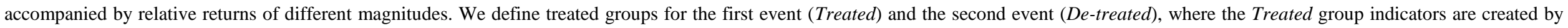

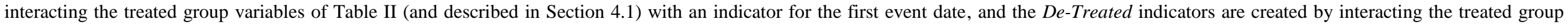

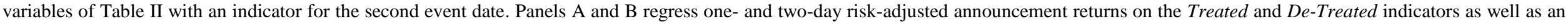

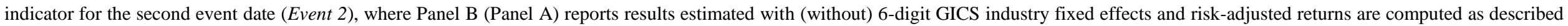

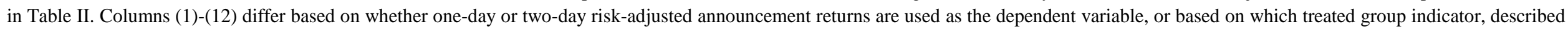

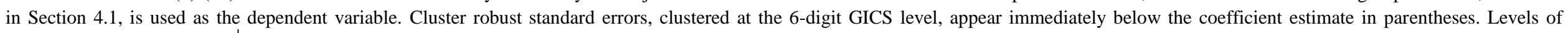
significance are indicated by ${ }^{+}, *, * *$, and $* * *$ for $15 \%, 10 \%, 5 \%$, and $1 \%$, respectively.

\section{Panel B: Industry Fixed Effects}

\begin{tabular}{|c|c|c|c|c|c|c|c|c|c|c|c|c|}
\hline & (1) & (2) & (3) & (4) & (5) & (6) & (7) & (8) & (9) & (10) & (11) & (12) \\
\hline & \multicolumn{2}{|c|}{ Treated-I } & \multicolumn{2}{|c|}{ Treated-II-up } & \multicolumn{2}{|c|}{ Treated-II-pl } & \multicolumn{2}{|c|}{ Treated-II-sm } & \multicolumn{2}{|c|}{ Treated-II-ti } & \multicolumn{2}{|c|}{ Treated-III } \\
\hline & 1-Day & 2-Day & 1-Day & 2-Day & 1-Day & 2-Day & 1-Day & 2-Day & 1-Day & 2-Day & 1-Day & 2-Day \\
\hline Treated & $\begin{array}{l}26.663^{+} \\
(16.90)\end{array}$ & $\begin{array}{c}71.643 * * * \\
(23.25)\end{array}$ & $\begin{array}{l}33.832^{+} \\
(22.28)\end{array}$ & $\begin{array}{c}102.228 * * * \\
(36.42)\end{array}$ & $\begin{array}{l}34.222 * \\
(18.92)\end{array}$ & $\begin{array}{c}87.664 * * * \\
(28.22)\end{array}$ & $\begin{array}{l}32.738 \\
(27.00)\end{array}$ & $\begin{array}{l}82.727 * \\
(41.69)\end{array}$ & $\begin{array}{l}20.957 \\
(15.19)\end{array}$ & $\begin{array}{c}47.070 * * \\
(18.65)\end{array}$ & $\begin{array}{l}36.467^{+} \\
(24.50)\end{array}$ & $\begin{array}{c}95.436 * * \\
(40.04)\end{array}$ \\
\hline De-Treated & $\begin{array}{l}12.192 \\
(12.08)\end{array}$ & $\begin{array}{l}-24.968 \\
(20.17)\end{array}$ & $\begin{array}{r}-12.073 \\
(15.44)\end{array}$ & $\begin{array}{c}-76.568 * * * \\
(26.83)\end{array}$ & $\begin{array}{c}15.183 \\
(12.54)\end{array}$ & $\begin{array}{l}-23.934 \\
(21.68)\end{array}$ & $\begin{array}{l}-8.323 \\
(18.75)\end{array}$ & $\begin{array}{c}-69.194 * * \\
(26.62)\end{array}$ & $\begin{array}{l}17.544 \\
(14.57)\end{array}$ & $\begin{array}{l}-29.737 \\
(27.35)\end{array}$ & $\begin{array}{l}-3.446 \\
(15.92)\end{array}$ & $\begin{array}{c}-71.082 * * \\
(27.19)\end{array}$ \\
\hline Event 2 & $\begin{array}{c}9.474 \\
(11.37)\end{array}$ & $\begin{array}{l}19.747 \\
(15.38)\end{array}$ & $\begin{array}{c}11.876 \\
(10.88)\end{array}$ & $\begin{array}{l}22.920^{+} \\
(14.48)\end{array}$ & $\begin{array}{c}9.741 \\
(11.44)\end{array}$ & $\begin{array}{l}19.503 \\
(15.21)\end{array}$ & $\begin{array}{l}10.858 \\
(10.95)\end{array}$ & $\begin{array}{l}18.253 \\
(14.93)\end{array}$ & $\begin{array}{c}7.602 \\
(10.82)\end{array}$ & $\begin{array}{c}12.77 \\
(15.23)\end{array}$ & $\begin{array}{l}10.938 \\
(11.02)\end{array}$ & $\begin{array}{l}20.293 \\
(14.76)\end{array}$ \\
\hline Cons & $\begin{array}{c}-9.060^{+} \\
(6.09) \\
\end{array}$ & $\begin{array}{c}-12.043^{+} \\
(7.72) \\
\end{array}$ & $\begin{array}{c}-8.374^{+} \\
(5.74) \\
\end{array}$ & $\begin{array}{c}-11.340^{+} \\
(7.55)\end{array}$ & $\begin{array}{c}-9.440^{+} \\
(6.28) \\
\end{array}$ & $\begin{array}{c}-12.504^{+} \\
(7.86) \\
\end{array}$ & $\begin{array}{r}-7.841 \\
(5.73) \\
\end{array}$ & $\begin{array}{c}-8.309 \\
(7.73) \\
\end{array}$ & $\begin{array}{l}-7.11 \\
(5.75) \\
\end{array}$ & $\begin{array}{l}-5.86 \\
(7.52) \\
\end{array}$ & $\begin{array}{l}-8.335 \\
(5.79) \\
\end{array}$ & $\begin{array}{l}-9.859 \\
(7.83) \\
\end{array}$ \\
\hline Observations & 5,265 & 5,265 & 5,265 & 5,265 & 5,265 & 5,265 & 5,265 & 5,265 & 5,265 & 5,265 & 5,265 & 5,265 \\
\hline F-Stat & 3.316 & 2.169 & 0.742 & 0.341 & 4.041 & 3.082 & 0.522 & 0.095 & 2.942 & 0.253 & 1.333 & 0.303 \\
\hline P-Val & 0.073 & 0.146 & 0.392 & 0.561 & 0.048 & 0.084 & 0.472 & 0.758 & 0.091 & 0.616 & 0.252 & 0.584 \\
\hline Adj. Rsq & 0.016 & 0.013 & 0.016 & 0.016 & 0.016 & 0.014 & 0.015 & 0.014 & 0.015 & 0.011 & 0.000 & 0.000 \\
\hline
\end{tabular}




\section{Table IV: Simulations}

Table IV reports summary statistics on the empirical distribution of OLS coefficients generated from estimating the specifications of Tables II and III (based on Treated-III group of firms) over all unique pairs of days over the non-event window of January $2^{\text {nd }}$ to June $30^{\text {th }}$ of 2010 . Panel A reports univariate distributional summary statistics of the coefficients simulated based on Tables II and III specifications. Rows [1] and [2] of Panel A summarize the distribution of simulated Treated-III coefficients for the no-fixed-effects and fixed-effects specifications in Panels A and B of Table II, respectively. Rows [3], [4], and rows [5], [6] summarize the distribution of the Treated and De-Treated coefficients simulated based on the nofixed-effects and fixed-effects specifications in Panels A and B of Table III, respectively. Panel B reports bivariate distributional summaries for the Treated and De-Treated coefficients. In particular, Panel B reports the proportion of the simulated coefficients that fall in specified ranges. For example, the (1,1)th cell in the No-Fixed-Effects panel of Panel B reports that $0.08 \%$ of the simulated pairs of Treated and De-Treated coefficients have a Treated coefficient that is less than or equal to -80 basis points and a De-Treated coefficient that is less than or equal to -80 basis points.

Panel A: Univariate Distributional Summary

\begin{tabular}{|c|c|c|c|c|c|}
\hline & $\begin{array}{c}(1) \\
\text { 1st Pctile }\end{array}$ & $\begin{array}{c}(2) \\
\text { Median } \\
\end{array}$ & $\begin{array}{c}(3) \\
\text { Mean }\end{array}$ & $\begin{array}{c}\text { (4) } \\
\text { 99th Pctile }\end{array}$ & $\begin{array}{c}(5) \\
\text { StdDev }\end{array}$ \\
\hline [1] Treated-III (No FE) & -63.03 & 2.86 & 3.95 & 73.53 & 29.76 \\
\hline [2] Treated-III (FE) & -56.19 & 2.45 & 2.87 & 66.47 & 26.35 \\
\hline [3] Treated (No FE) & -100.58 & 7.06 & 6.69 & 109.40 & 42.42 \\
\hline [4] De-Treated (No FE) & -102.36 & 4.03 & -1.19 & 83.97 & 41.75 \\
\hline [5] Treated (FE) & -82.64 & 5.79 & 7.00 & 109.06 & 41.13 \\
\hline [6] De-Treated (FE) & -86.68 & 1.02 & -0.77 & 88.44 & 38.23 \\
\hline
\end{tabular}

Panel B: Bivariate Distributional Summary

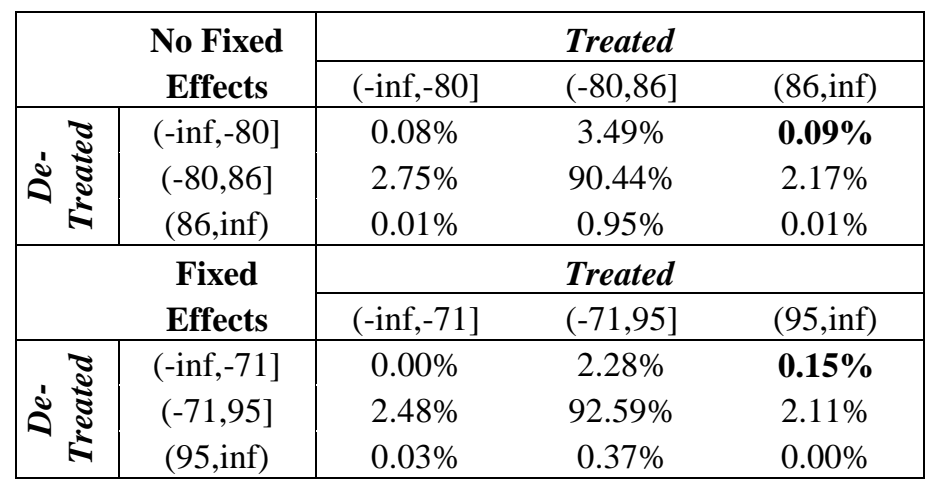




\section{Table V: Robustness Test - Different Meeting Month Cutoffs}

Table V reports a robustness test for the pooling specification presented in Table II column (12). In Panels A and B, each column differs based on the meeting month cutoff used to define treated groups. For example, Treated in column (1) is defined to be those with staggered boards, whose last annual meeting took place on or after the month of February, and have at least two of the four dimensions of firm or industry characteristics which make control contests particularly relevant: underperformance, high asset pledgibility, small size, and high industry takeover intensity. In Panel B we include 6-digit GICS industry fixed effects but not in Panel A. In all specifications we use cluster robust standard errors, clustered at the 6-digit GICS level, which appear immediately below the coefficient estimate in parentheses. Levels of significance are indicated by ${ }^{+}, *, * *$, and $* * *$ for $15 \%, 10 \%, 5 \%$, and $1 \%$, respectively.

\section{Panel A: No Industry Fixed Effects}

\begin{tabular}{|c|c|c|c|c|c|c|c|c|c|}
\hline & $\begin{array}{c}(1) \\
\text { Month } \geq \text { Feb }\end{array}$ & $\begin{array}{c}(2) \\
\text { Month } \geq \text { Mar }\end{array}$ & $\begin{array}{c}(3) \\
\text { Month } \geq \text { Apr }\end{array}$ & $\begin{array}{c}(4) \\
\text { Month } \geq \text { May }\end{array}$ & $\begin{array}{c}(5) \\
\text { Month } \geq \text { Jun }\end{array}$ & $\begin{array}{c}(6) \\
\text { Month } \geq \text { Jul }\end{array}$ & $\begin{array}{c}(7) \\
\text { Month } \geq \text { Aug }\end{array}$ & $\begin{array}{c}(8) \\
\text { Month } \geq \text { Sep }\end{array}$ & $\begin{array}{c}\text { (9) } \\
\text { Month } \geq \text { Oct }\end{array}$ \\
\hline Treated & $\begin{array}{c}35.117 * * \\
(15.35)\end{array}$ & $\begin{array}{c}39.816^{* * * *} \\
(14.70)\end{array}$ & $\begin{array}{c}40.141 * * * \\
(14.69)\end{array}$ & $\begin{array}{c}47.590 * * * \\
(16.39)\end{array}$ & $\begin{array}{c}83.259 * * * \\
(25.96)\end{array}$ & $\begin{array}{c}101.430 * * * \\
(34.47)\end{array}$ & $\begin{array}{c}85.678 * * \\
(41.30)\end{array}$ & $\begin{array}{c}108.913 * \\
(57.06)\end{array}$ & $\begin{array}{l}84.686^{+} \\
(57.19)\end{array}$ \\
\hline Event 2 & $\begin{array}{l}-2.824 \\
(18.22)\end{array}$ & $\begin{array}{l}-2.824 \\
(18.22)\end{array}$ & $\begin{array}{l}-2.824 \\
(18.22)\end{array}$ & $\begin{array}{l}(2.824) \\
(18.22)\end{array}$ & $\begin{array}{l}-2.824 \\
(18.22)\end{array}$ & $\begin{array}{l}(2.822) \\
(18.22)\end{array}$ & $\begin{array}{l}-2.821 \\
(18.22)\end{array}$ & $\begin{array}{l}(2.821) \\
(18.22)\end{array}$ & $\begin{array}{l}-2.821 \\
(18.22)\end{array}$ \\
\hline Cons & $\begin{array}{l}-9.053 \\
(13.96) \\
\end{array}$ & $\begin{array}{l}-9.882 \\
(13.78) \\
\end{array}$ & $\begin{array}{l}-9.771 \\
(13.81) \\
\end{array}$ & $\begin{array}{l}-10.305 \\
(14.12) \\
\end{array}$ & $\begin{array}{l}-8.735 \\
(13.32) \\
\end{array}$ & $\begin{array}{l}-4.479 \\
(13.33) \\
\end{array}$ & $\begin{array}{l}-3.264 \\
(13.71) \\
\end{array}$ & $\begin{array}{l}-3.078 \\
(13.71) \\
\end{array}$ & $\begin{array}{l}-2.209 \\
(13.64) \\
\end{array}$ \\
\hline Observations & 5,265 & 5,265 & 5,265 & 5,265 & 5,265 & 5,265 & 5,265 & 5,265 & 5,265 \\
\hline Adj. Rsq & 0.001 & 0.002 & 0.002 & 0.002 & 0.004 & 0.002 & 0.001 & 0.001 & 0.000 \\
\hline
\end{tabular}

Panel B: Industry Fixed Effects

\begin{tabular}{|c|c|c|c|c|c|c|c|c|c|}
\hline & $\begin{array}{c}(1) \\
\text { Month } \geq \text { Feb }\end{array}$ & $\begin{array}{c}(2) \\
\text { Month } \geq \text { Mar }\end{array}$ & $\begin{array}{c}(3) \\
\text { Month } \geq \mathbf{A p r}\end{array}$ & $\begin{array}{c}\text { (4) } \\
\text { Month } \geq \text { May }\end{array}$ & $\begin{array}{c}(5) \\
\text { Month } \geq \text { Jun }\end{array}$ & $\begin{array}{c}(6) \\
\text { Month } \geq \text { Jul }\end{array}$ & $\begin{array}{c}(7) \\
\text { Month } \geq \text { Aug }\end{array}$ & $\begin{array}{c}(8) \\
\text { Month } \geq \text { Sep }\end{array}$ & $\begin{array}{c}(9) \\
\text { Month } \geq \text { Oct }\end{array}$ \\
\hline Treated & $\begin{array}{c}34.667 * * \\
(15.75)\end{array}$ & $\begin{array}{c}39.427 * * \\
(15.24)\end{array}$ & $\begin{array}{c}39.852 * * \\
(15.14)\end{array}$ & $\begin{array}{c}44.770 * * * \\
(16.80)\end{array}$ & $\begin{array}{c}80.439 * * * \\
(26.12)\end{array}$ & $\begin{array}{c}100.763 * * * \\
(34.84)\end{array}$ & $\begin{array}{c}85.084 * * \\
(42.53)\end{array}$ & $\begin{array}{c}108.491 * \\
(57.60)\end{array}$ & $\begin{array}{l}88.673^{+} \\
(55.04)\end{array}$ \\
\hline Event 2 & $\begin{array}{l}-2.810 \\
(18.34)\end{array}$ & $\begin{array}{l}-2.810 \\
(18.34)\end{array}$ & $\begin{array}{l}-2.810 \\
(18.34)\end{array}$ & $\begin{array}{l}(2.810) \\
(18.34)\end{array}$ & $\begin{array}{l}-2.809 \\
(18.34)\end{array}$ & $\begin{array}{l}(2.806) \\
(18.34)\end{array}$ & $\begin{array}{l}-2.806 \\
(18.34)\end{array}$ & $\begin{array}{l}(2.806) \\
(18.34)\end{array}$ & $\begin{array}{l}-2.806 \\
(18.34)\end{array}$ \\
\hline Cons & $\begin{array}{r}-8.957 \\
(9.80) \\
\end{array}$ & $\begin{array}{l}-9.803 \\
(9.47) \\
\end{array}$ & $\begin{array}{l}-9.715 \\
(9.51) \\
\end{array}$ & $\begin{array}{l}-9.763 \\
(9.79) \\
\end{array}$ & $\begin{array}{c}-8.482 \\
(8.81)\end{array}$ & $\begin{array}{c}-4.464 \\
(8.93)\end{array}$ & $\begin{array}{c}-3.256 \\
(9.36)\end{array}$ & $\begin{array}{c}-3.077 \\
(9.37)\end{array}$ & $\begin{array}{l}-2.271 \\
(9.22)\end{array}$ \\
\hline Observations & 5,265 & 5,265 & 5,265 & 5,265 & 5,265 & 5,265 & 5,265 & 5,265 & 5,265 \\
\hline Adj. Rsq & 0.004 & 0.005 & 0.005 & 0.005 & 0.006 & 0.005 & 0.004 & 0.004 & 0.004 \\
\hline
\end{tabular}




\section{Table V: Robustness Test - Different Meeting Month Cutoffs (Cont’d)}

Table V reports a robustness test for the pooling specification presented in Table II column (12). Panel C reports OLS estimation results from regressing two-day risk-adjusted returns on an adjusted Treated-III indicator, the month of last annual meeting, an interaction of the Treated-III indicator with month of last annual meeting, and an indicator for the second event date (Event 2). We adjust the definition of Treated-III group of firms by removing from the definition a firm's last annual meeting month: a firm is in the Treated-III group of firms if it has a staggered board and have at least two of the four dimensions of firm or industry characteristics which make control contests particularly relevant: underperformance, high asset pledgibility, small size, and high industry takeover intensity. In both specifications we use cluster robust standard errors, clustered at the 6-digit GICS level, which appear immediately below the coefficient estimate in parentheses. Levels of significance are indicated by ${ }^{+}, * * *$, and $* * *$ for $15 \%, 10 \%, 5 \%$, and $1 \%$, respectively.

\section{Panel C: Interaction Model}

\begin{tabular}{lcc}
\hline \hline & $(1)$ & $(2)$ \\
& Treated-III & Treated-III \\
\hline Treated X Month & $16.372^{* *}$ & $17.314^{* *}$ \\
& $(7.21)$ & $(6.95)$ \\
Month & -38.319 & -41.989 \\
& $(35.14)$ & $(35.34)$ \\
Treated & 3.033 & 1.887 \\
& $(2.43)$ & $(2.83)$ \\
Event 2 & -3.973 & -3.959 \\
& $(18.20)$ & $(18.32)$ \\
Cons & -22.407 & -17.349 \\
& $(16.03)$ & $(14.88)$ \\
\cline { 2 - 3 } Industry Fixed Effects & No & Yes \\
Observations & 5,243 & 5,243 \\
Adj. Rsq & 0.003 & 0.006 \\
\hline \hline
\end{tabular}

